\title{
Diurnal and seasonal variations in the photosynthetic performance and chlorophyll fluorescence of cassava 'Rayong 9' under irrigated and rainfed conditions
}

\author{
K. VONGCHAROEN ${ }^{*}$, S. SANTANOO ${ }^{* *}$, P. BANTERNG ${ }^{* * *}$, S. JOGLOY ${ }^{* * *}$, N. VORASOOT ${ }^{* * *}$, and \\ P. THEERAKULPISUT ${ }^{*, * *++}$
}

\author{
Department of Biology, Faculty of Science, Khon Kaen University, Khon Kaen 40002, Thailand \\ Salt-tolerant Rice Research Group, Department of Biology, Faculty of Science, Khon Kaen University, \\ Khon Kaen 40002, Thailand ${ }^{* *}$ \\ Department of Plant Science and Agricultural Resources, Faculty of Agriculture, Khon Kaen University, \\ Khon Kaen 40002, Thailand ${ }^{* * *}$
}

\begin{abstract} photosystem II.

Introduction

Global change effects on climate are likely to produce warmer and drier conditions and more frequent and stronger droughts including the tropical regions of Asia. Water limitation considered as the main factor, either alone or combined with other unfavorable conditions, seriously limits agricultural productivity around the world (IPCC 2001, Chaves and Oliveira 2004, Murchie et al. 2008, Flexas et al. 2009). Photosynthesis as the primary process by which plants use light energy to drive the synthesis of organic compounds, is pivotal for crop growth and productivity. Water stresses of varying severity and duration can reduce photosynthetic carbon assimilation (Vitolo et al. 2012, Bertolli and Souza 2013). The survival of a plant in drought environment depends largely upon its ability to photosynthesize with an adequate rate in order to grow faster than its competitors and to maintain positive water balance (Wuenscher and Kozlowski 1971).
\end{abstract}

Diurnal photosynthesis responses of cassava cultivar Rayong 9 ('RY9') three months after planting, grown in a field conditions under irrigated and rainfed conditions, were evaluated during the rainy, cool, and hot seasons. Under the mild conditions of the rainy and cool seasons, net photosynthetic rates $\left(P_{\mathrm{N}}\right)$ increased in parallel with light intensity and attained the maximum at 13.00 or $11.00 \mathrm{~h}$. In the hot season, $P_{\mathrm{N}}$ attained the prominent peak at $9.00 \mathrm{~h}$, after which stomatal conductance decreased rapidly coordinated with declining $P_{\mathrm{N}}$ and nonphotochemical quenching was enhanced. Photosynthetically active radiation was the major factor influencing $P_{\mathrm{N}}$ in the rainy and cool seasons, whereas vapor pressure deficit was the major factor in the hot season. 'RY9' adapted extremely well in this climate because the maximal quantum yield of PSII photochemistry recovered fully in the evening even under the rainfed conditions in the hot season.

Additional key words: chlorophyll fluorescence; diurnal gas exchange; Manihot esculenta; nonphotochemical quenching;

The photosynthetic capacity of leaves depends on the characteristics and amounts of the components of the photosynthetic machinery, the production of which depends on the availability of water, light, temperature, nutrients, etc. (El-Sharkawy 2012). Under natural field conditions, the assimilatory apparatus is exposed to variable intensities of light, temperature, and humidity that may result in a typical midday depression of $\mathrm{CO}_{2}$ assimilation or photoinhibition (Hirasawa and Hsiao 1999). The midday depression of photosynthesis, a common phenomenon for many $\mathrm{C}_{3}$ and $\mathrm{C}_{4}$ plants, is exacerbated under the conditions of water limitation as well as heat stress (Huang et al. 2006). In general, drought stress negatively impacted leaf gas exchange and stomatal conductance $\left(g_{\mathrm{s}}\right)$ decreased more than other physiological traits of $\mathrm{C}_{3}$ plants including cassava. The decrease in $g_{\mathrm{s}}$ mainly reduced the transpiration rate $(E)$, and the reduction in $g_{\mathrm{s}}$ could explain $55 \%$ of the decrease in the photosynthetic rate and $74 \%$ of the decline in $E$ (Weiming et al. 2016). Cassava leaves open stomata

$\overline{\text { Received }} 14$ May 2018, accepted 16 August 2018.

${ }^{+}$Corresponding author; e-mail: piythe@kku.ac.th

Abbreviations: $C_{\mathrm{a}}$ - ambient $\mathrm{CO}_{2}$ concentration; $\mathrm{Chl}$ - chlorophyll; ChlF - chlorophyll fluorescence; $C_{\mathrm{i}}-$ intercellular $\mathrm{CO}_{2}$ concentration; ETR - electron transport rate; $\mathrm{F}_{\mathrm{v}} / \mathrm{F}_{\mathrm{m}}$ - maximal quantum yield of PSII photochemistry; $g_{\mathrm{s}}-$ stomatal conductance; NPQ nonphotochemical quenching; $P_{\mathrm{N}}-$ net photosynthetic rate; $\Phi_{\mathrm{PSII}}-$ effective quantum yield of PSII photochemistry; $\mathrm{T}_{\text {air }}-$ air temperature; VPD - vapor pressure deficit.

Acknowledgments: This project was financially supported by the Thailand Research Organizations Network (TRON) administered by the National Science and Technology Development Agency (NSTDA). The authors also acknowledge the Thailand Research Fund (Project code: IRG5780003) and Faculty of Agriculture, Khon Kaen University for providing financial support for manuscript preparation activities. 
in the morning when the vapor pressure deficit (VPD) is lower than $2 \mathrm{kPa}$ (El-Sharkawy and Cock 1984). During the day with increasing light intensity and VPD (higher than $2 \mathrm{kPa}$ ), stomata start narrowing its pores to reduce water loss (De Tafur et al. 1997, El-Sharkawy 2012). In addition, leaves of cassava are able to adjust blade angle by 'drooping or folding downward' at midday away from solar radiation to reduce area receiving light, which reduces leaf temperature and water loss (El-Sharkawy and Cock 1984, Berg et al. 1986). Leaf movement of cassava allows tracking sun radiation (heliotropism) when VPD is low (i.e., early morning and late afternoon), while avoiding direct sun radiation (paraheliotropism) when VPD is greatest (i.e., midday), thus enhancing leaf water-use efficiency $\left(\mathrm{CO}_{2}\right.$ uptake/ $\mathrm{H}_{2} \mathrm{O}$ loss) (El-Sharkawy 2004). On one hand, solar tracking movement enhances interception of light at low sun angle occurring early morning and late afternoon, thus resulting in higher carbon uptake at a time when VPD is lowest. On the other hand, downward movement of leaves during midday, when VPD is greatest, decreases light interception, hence, lower leaf temperature, and less transpirational water losses, while leaf $P_{\mathrm{N}}$ is slightly reduced. These two movements are crucial for optimizing leaf water-use efficiency in cassava (El-Sharkawy 2007). Photosynthetic performance which varies during the day due to the variability of light intensity can be used to describe the whole plant response (Huner et al. 1998). Diurnal light intensity varies in different seasons due to changes in sun angle and cloud cover in addition to shading from overlapping leaves and neighboring plants. Therefore, leaves are subjected to spatial and temporal gradients in incident light, which has major consequences for photosynthetic carbon assimilation (Pearcy 1990, Chazdon and Pearcy 1991, Pearcy and Way 2012). Under natural environmental conditions, the random duration and intensity of fluctuating light from passing clouds or leaf movements (sun flecks and shade flecks) result in incident light intensities below light saturation, thus reducing photosynthetic rates. On the contrary, those intensities greater than light saturation lead to excess excitation energy that can result in short potential stress periods and long-term damage to leaf photosynthesis (Baker 2008).

During photosynthesis, $\sim 5 \%$ of absorbed light energy by PSII is reemitted as chlorophyll fluorescence (ChlF). The measurement of ChlF by pulse-amplitude modulated (PAM) fluorometry associated with PSII is widely used as noninvasive and rapid method to monitor the functional state of photosynthetic machinery in organisms (Rosenqvist and van Kooten 2003). Fluorescence emissions in photosynthetic organisms can be correlated to their photosynthetic rates (Logan et al. 2007, Durako 2012). The responses of vegetation to stresses observed by ChlF, which can be applied rapidly and in a nondestructive manner, gives insight into the ability of plants to tolerate environmental stresses and the extent to which these stresses may have in inhibiting or damaging the photosynthetic apparatus in plants (Logan et al. 2007, Baker 2008).

Photosynthetic performance of a single leaf can abruptly change during the day depending on the fluctua- tion in environmental factors, particularly the light intensity (Vitolo et al. 2012). Photosynthetic capacity depends on both the efficiency of light-dependent and net $\mathrm{CO}_{2}$ fixation reactions (Parry et al. 2011). The efficiency of light-dependent reaction is largely indicated by the measurement of effective quantum yield of PSII photochemistry $\left(\Phi_{\mathrm{PSII}}\right)$ which determines relative electron transport rate (ETR) (Li et al. 2015). Net $\mathrm{CO}_{2}$ fixation rate $\left(P_{\mathrm{N}}\right)$ depends on stomatal and nonstomatal factors which are in turn controlled by external environmental factors and biochemical characteristics of plant cells (Saibo et al. 2009). Diurnal variation in $\Phi_{\mathrm{PSII}}$ is largely controlled by light intensity being lowered with increasing PAR as reported by Hazrati et al. (2016). According to Zha et al. (2017) diurnal variation in $\Phi_{\text {PSII }}$ of a desert plant, Artemisia ordosica, was negatively correlated with PAR, and diurnal regression slopes of $\Phi_{\text {PSII }} v s$. PAR varied seasonally in response to changes in environmental factors. The regression slopes decreased with increasing stressful conditions, i.e., higher temperature and VPD, and severe water stress. The diurnal and seasonal changes in $\Phi_{\text {PSII }}$ and $P_{\mathrm{N}}$ in leaves of Prosopis juliflora subjected to natural environmental stress was investigated during winter and summer by Shirke and Pathre (2003). Under the mild winter conditions, with cold nights $\left(2-8^{\circ} \mathrm{C}\right)$ and moderate temperatures during the day, the plants showed high $\Phi_{\text {PSII }}$ and $P_{\mathrm{N}}$. In summer, the midday temperatures often reached nearly $<45^{\circ} \mathrm{C}$ and plants showed severe inhibition of photosynthesis (midday depression). The rate of photosynthesis is also determined by characteristics of plants, such as morphology, anatomy, canopy structure, plant age, leaf age and position, stomatal behavior, pigments, and molecular machinery of chloroplast which also varied with environmental conditions (Okogbenin et al. 2010, Turyagyenda et al. 2013, Oliveira and Miglioranza 2014).

Cassava (Manihot esculenta Crantz) is a perennial woody shrub of the Euphorbiaceae family and is considered a staple food of more than a billion people in almost 105 countries (Chetty et al. 2013). It is the important crop cultivated in almost all areas in the tropical zone and subtropical Africa, Asia, and Latin America (ElSharkawy 2006, Okogbenin et al. 2013). It is typically cultivated by families for their own consumption on small plots of land, although in Asia and some regions of Latin America it is also grown commercially and on large fields (Nassar and Ortiz 2010). In addition to the tuberous roots, the main harvested product, cassava leaves are consumed as a vegetable in at least $60 \%$ of the countries in subSaharan Africa, providing an important source of proteins, vitamins, and micronutrients (Lancaster and Brooks 1983, Latif and Muller 2015). Cassava leaves are also used as a protein supplement for livestock (Ravindra 1993, Lukuyu et al. 2014).

Diurnal variation in photosynthesis is generally recognized to reflect the ability of a plant to maintain the photosynthetic apparatus and to respond readily to environmental factors (Geiger and Servaites 1994, Ding et al. 2006). Therefore, analyzing the photosynthetic status of a plant can provide valuable information for evaluating 
its adaptive potential for crop yield improvement and for introduction into a new environment ( $\mathrm{Li}$ et al. 2015). Information on seasonal variation in diurnal photosynthetic gas exchange and ChlF of cassava in response to changes in environmental conditions during the day has not been adequately addressed. Our interest of this study was to acquire a better understanding of diurnal patterns of leaf photosynthesis and ChlF performance of a commercially important cultivar of cassava ('RY9') as affected by different climatic conditions in rainy, cool, and hot seasons in an experimental field under irrigation and rainfed conditions. Thailand was the second largest producer of cassava, after Nigeria, in 2017 (FAO 2017), and more than $50 \%$ of cassava is being cultivated in drought-prone areas in the northeastern part of the country (Office of Agricultural Economics 2018). Therefore, understanding the behavior of photosynthetic responses of rainfed and well-watered cassava plants in each season can be useful for management of cassava planting and agronomic practice to obtain optimal photosynthetic capacity of cassava. Nevertheless, a wider range of cassava germplasm need to be evaluated in order to assist crop breeding programs in selecting improved cultivars adapted to climate change under specific environment.

\section{Materials and methods}

Study site: The experiment was conducted during April 2015 to May 2016 at the Field Crop Research Station of the Division of Agronomy, Faculty of Agriculture, Khon Kaen University $\left(1647^{\prime} \mathrm{N}, 102^{\circ} 81^{\prime} \mathrm{E}, 195 \mathrm{~m}\right.$ a. s. 1.). The soil texture was sandy loam (Oxic Paleustult) (Keeratikasikorn 1991). The climate of Thailand can be divided into three seasons as follows: rainy season (May-October), cool season (November-February), and summer (March-May) (Thai Meteorological Department 2016).

Weather conditions and soil matric potential: The weather at the study site was recorded by an automatic data logger model Watchdog 2700 (Watchdog, PCE group, PCE Germany, Meschede, Germany). Data were recorded for relative humidity $(\mathrm{RH})$, temperature, $\mathrm{PAR}$, and rainfall at intervals of $5 \mathrm{~min}$ during the entire observation period (Table 1S, supplement). Soil matric potential of both the irrigated and rainfed plots was monitored during the entire study period by using the watermark probe (Watchdog 1645, PCE group, PCE Germany, Meschede, Germany) placed at the depth of $20 \mathrm{~cm}$. The soil suction at $20 \mathrm{~cm}$ depth in the irrigated plots was maintained well above $-30 \mathrm{kPa}$ below which irrigation was immediately supplied by a mini-overhead sprinkler system (Fig. 1S, supplement).

Plants and cultivation practices: Cassava (Manihot esculenta Crantz) cv. RY9 was used in this study. The stem cuttings, $20 \mathrm{~cm}$ in length, of cassava were planted in ridges at $1 \times 1 \mathrm{~m}$ distance in the $5 \times 7 \mathrm{~m}$ plot under irrigated and rainfed conditions. Cassava was planted on 30 June 2015 (June planting date), 10 November 2015 (November planting date), and 15 December 2015 (December planting date). During the first $30 \mathrm{~d}$ after planting, both irrigated and rainfed plots were irrigated (using a mini-overhead sprinkler system) to the level close to the field capacity to enhance good crop establishment. After the first month, irrigation was applied only to the irrigated plots when required, whereas the rainfed plots remained without irrigation throughout the entire period of this study. At the irrigated plots, irrigation was applied whenever the soil matric potential at $20-\mathrm{cm}$ depth was lower than $-30 \mathrm{kPa}$ and water was supplied until the soil matric potential increased to $0 \mathrm{kPa}$. Before planting, manure was applied to the soils at the rate of $6.25 \mathrm{tha}^{-1}$, and the soil $\mathrm{pH}$ was adjusted to $6.5-7.5$ by adding lime as recommended by Watson and Brown (1998). Manual weeding was practiced after one and two months from planting and chemical fertilizer $\left(15-7-18\right.$ of $\left.\mathrm{N}-\mathrm{P}_{2} \mathrm{O}_{5}-\mathrm{K}_{2} \mathrm{O}\right)$ was applied at the rate of $0.3 \mathrm{t} \mathrm{ha}^{-1}$ according to Howeler (2003). In addition, the field was monitored twice weekly, and no diseases and pest were found during the period of study. For diurnal photosynthesis studies, data were collected from plants after three months from planting (MAP). The aforementioned stage of growth was selected for the study of photosynthesis performance because near maximum vegetative growth and canopy development (leaf and stem growth) were achieved during this period (Alves 2002, Edet et al. 2015).

Diurnal photosynthetic gas exchange: The effects of different environmental conditions in different seasons on diurnal photosynthesis performance of cassava were investigated in 3-month-old plants during three seasons. The measurements during the rainy, cool, and hot seasons were performed on June, November, and December planted plants, respectively. For each plant, diurnal photosynthesis performance was investigated on the upper, middle, and lower canopy leaf position. The main stem of the plant was vertically divided into three equal sections. The upper, middle, and lower canopy leaf was defined as the one located in the middle of the top, middle, and lower stem section, respectively.

Diurnal photosynthetic gas exchange was measured using a portable photosynthesis system (LI-COR 6400XT, $L I-C O R$, Lincoln, Nebraska, USA) in a standard $2 \times 3 \mathrm{~cm}$ leaf chamber (6400-08 clear chamber bottom) with ambient $\mathrm{CO}_{2}$ concentration (373-428 $\mu \mathrm{mol} \mathrm{mol} \mathrm{mon}^{-1}$ ) under natural light intensity with ambient air temperature. The measurements were made at 2-h intervals from 05.00 $19.00 \mathrm{~h}$ on two sunny days (rainy season: 28 September and 2 October 2015, cool season: 24 and 26 February 2016, hot season: 3 and 5 April 2016) from two randomly selected plants, each from the irrigated and rainfed plots. For each time point, the measurement was done at the irrigated plot first followed by the rainfed plot with less than 10-min time lapse. Measurements were done at the central lobe of fully expanded leaves in upper, middle, and lower canopy of the main stem. The recorded photosynthetic parameters included $P_{\mathrm{N}}, g_{\mathrm{s}}$, intercellular $\mathrm{CO}_{2}$ concentration $\left(C_{\mathrm{i}}\right), \mathrm{PAR}$, 
$\mathrm{RH}$, air temperature $\left(\mathrm{T}_{\text {air }}\right)$, and ambient $\mathrm{CO}_{2}$ concentration $\left(C_{\mathrm{a}}\right)$.

Chl fluorescence: Diurnal ChlF was measured on the same leaf used to measure diurnal photosynthetic gas exchange. ChlF was performed first immediately after gas-exchange measurement with less than 3-min time lapse. The instrument used was a portable pulse amplitude modulated photosynthesis yield analyzer (Mini-PAM, Heinz Walz, Effeltrich, Germany). Measurements for determination of the minimal fluorescence yield of the dark-adapted state $\left(\mathrm{F}_{0}\right)$ and maximal fluorescence yield of the dark-adapted state $\left(\mathrm{F}_{\mathrm{m}}\right)$ were performed at predawn $(5: 00 \mathrm{~h})$ and at night $(19: 00 \mathrm{~h})$. Variable fluorescence $\left(\mathrm{F}_{\mathrm{v}}\right)$ in the dark-adapted state was calculated as: $\mathrm{F}_{\mathrm{v}}=\mathrm{F}_{\mathrm{m}}-\mathrm{F}_{0}$ and the maximal quantum efficiency of PSII photochemistry was calculated using the formula: maximal quantum yield of PSII photochemistry $\left(\mathrm{F}_{\mathrm{v}} / \mathrm{F}_{\mathrm{m}}\right)=\left(\mathrm{F}_{\mathrm{m}}-\mathrm{F}_{0}\right) / \mathrm{F}_{\mathrm{m}}$. Steadystate fluorescence in the light-adapted state $\left(\mathrm{F}_{\mathrm{s}}\right)$ and the maximal fluorescence yield of the light-adapted state $\left(\mathrm{F}_{\mathrm{m}}{ }^{\prime}\right)$ were measured during the day every two hours between 7:00-17:00 h. The effective quantum yield of PSII photochemistry $\left(\Phi_{\text {PSII }}\right)$ and nonphotochemical quenching (NPQ) were determined as: $\Phi_{\text {PSII }}=\left(F_{\mathrm{m}}{ }^{\prime}-\mathrm{F}_{\mathrm{s}}\right) / \mathrm{F}_{\mathrm{m}}{ }^{\prime}$ and $\mathrm{NPQ}=\left(\mathrm{F}_{\mathrm{m}} / \mathrm{F}_{\mathrm{m}}{ }^{\prime}\right)-1$ (Genty et al. 1989, Kalaji et al. 2014). The electron transport rate (ETR) was calculated as: $\mathrm{ETR}=\Phi_{\text {PSII }} \times \mathrm{I} \times \mathrm{f} \times \alpha_{\text {leaf }}$, where $\mathrm{I}$ is the incident photon flux density $\left[\mu \mathrm{mol}\right.$ (photon) $\left.\mathrm{m}^{-2} \mathrm{~s}^{-1}\right], \mathrm{f}=0.5$ is the factor that accounts for the partitioning of energy between PSII and PSI, and $\alpha_{\text {leaf }}$ is the leaf absorptance. A value of 0.84 was used for $\alpha_{\text {leaf }}$, regardless of possible inherent anatomical, biochemical, and physiological differences between leaves of different canopy levels. Light absorptance might be affected by leaf mesophyll characteristics (Li and Chen 2009).

Data analysis: A correlation between $P_{\mathrm{N}}$ and environmental factors (Pearson's correlation coefficient) was evaluated using a MSTAT-C Version 1.42 program (Freed and Nissen 1992). All statistical analyses were carried out following the procedure described by Gomez and Gomez (1984) and the SPSS version 19 software package (SPSS Inc., Chicago, IL, USA).

\section{Results}

Climatic data of the study site: Total precipitation during the rainy (June-October 2015), cool (November 2015February 2016), and hot (March-May 2016) seasons were 702.2, 20.2, and $152 \mathrm{~mm}$, respectively. The maximum $\mathrm{RH}$ values during the rainy, cool, and hot seasons were $92.8,82.0$, and $83.9 \%$, respectively. At predawn, the $\mathrm{RH}$ was higher than $90 \%$ throughout the growing season and minimum RH (occurring around 14:00-15:00 h) varied considerably in different seasons (Fig. 1). The average monthly temperatures during the rainy, cool, and hot months were $28.0,25.5$, and $31.1^{\circ} \mathrm{C}$, respectively. The maximum temperatures were similar during the rainy $\left(39.7^{\circ} \mathrm{C}\right)$ and cool $\left(38.7^{\circ} \mathrm{C}\right)$ seasons but were considerably higher in the hot season $\left(43.9^{\circ} \mathrm{C}\right)$. The coldest night tem- peratures were recorded in January $2016\left(9.2^{\circ} \mathrm{C}\right)$ and February $2016\left(8.9^{\circ} \mathrm{C}\right)$.

The average soil matric potential at the irrigated plots ranged between -3.44 (May 2016) to -16.03 (November 2015) $\mathrm{kPa}$, indicating good water supply throughout the growing season. The rainfed plots, on the other hand, experienced lower available water expressing the soil matric potentials between -39.85 to $-88.51 \mathrm{kPa}$ during January-May 2016. The monthly average soil matric potentials in the irrigated and rainfed plots at the $20-\mathrm{cm}$ soil depth are shown in Fig. 1S. The average soil matric potential in the irrigated plots during the rainy, cool, and hot seasons were $-11.9,-14.2$, and $-11.3 \mathrm{kPa}$, respectively, and in the rainfed plots during the rainy, cool, and hot seasons were $-7.2,-32.6$, and $-76.0 \mathrm{kPa}$, respectively.

Climatic data on the days of measurement of photosynthesis in the irrigated and rainfed field conditions in different seasons: PAR varied among seasons, it was low in the early morning, increasing with time, and reaching a maximum at noon, thereafter PAR continuously decreased. The diurnal average PAR from the two-day investigations in each season is depicted in Fig. 2; it shows the maximum PARs during the rainy, cool, and hot seasons of 2,043; 1,753; and 2,060 $\mu$ mol(photon) $\mathrm{m}^{-2} \mathrm{~s}^{-1}$, respectively (Fig. 2). PAR during rainy season considerably fluctuated due to cloud cover.

The average soil matric potentials were $-7.0,-18.9$, and $-12.4 \mathrm{kPa}$ at the irrigated fields during the rainy, cool, and hot seasons, respectively, whereas those in the rainfed were $-22.8,-52.3$, and $-90.7 \mathrm{kPa}$, respectively (Table $1 \mathrm{~S}$ - supplement). Average $\mathrm{RH}$ in the irrigated field during the rainy, cool, and hot seasons were 83.0, 53.0, and 56.1\%, respectively, whereas those in the rainfed fields were 90.3 , 46.5 , and $43.4 \%$, respectively (Table $1 \mathrm{~S}$ ). The average temperatures in the irrigated plots during the rainy, cool, and hot seasons were $27.8,24.7$, and $25.8^{\circ} \mathrm{C}$, respectively, whereas those in the rainfed conditions were 28.1, 24.5, and $31.9^{\circ} \mathrm{C}$, respectively. The maximum and minimum temperatures in the rainfed plots during the hot and cool season were 40.5 and $18.3^{\circ} \mathrm{C}$, respectively (Table $1 \mathrm{~S}$ ).

Diurnal changes of photosynthetic parameters: In the rainy season, diurnal photosynthesis and environmental parameters during the two typical sunny days of photosynthesis measurements are presented in Figs. 3, 4. The PAR, $\mathrm{T}_{\text {air }}$, and VPD were increasing from the early morning to reach the maximum at $13: 00 \mathrm{~h}$ and then decreasing thereafter, whereas $\mathrm{RH}$ changes occurred in the opposite direction (Fig. $3 A-H$ ). $P_{N}$ was negative at predawn, increased sharply (for upper canopy leaves) and slightly (for middle and lower canopy leaves) in the morning, and reached a maximum at about 13:00 h, then abruptly decreased in the afternoon and exhibited negative values at 19:00 h. The maximum $P_{\mathrm{N}}$ for the upper, middle, and lower canopy leaves of plants growing under irrigation were $28.7,16.2$, and $8.6 \mu \mathrm{mol}\left(\mathrm{CO}_{2}\right)$ $\mathrm{m}^{-2} \mathrm{~s}^{-1}$, respectively, corresponding to the respective maximum PAR at the leaf surface of 1,$690 ; 1,042$; and 422 $\mu \mathrm{mol}\left(\right.$ photon) $\mathrm{m}^{-2} \mathrm{~s}^{-1}$ (Fig. $4 A$ ). Under rainfed conditions, 


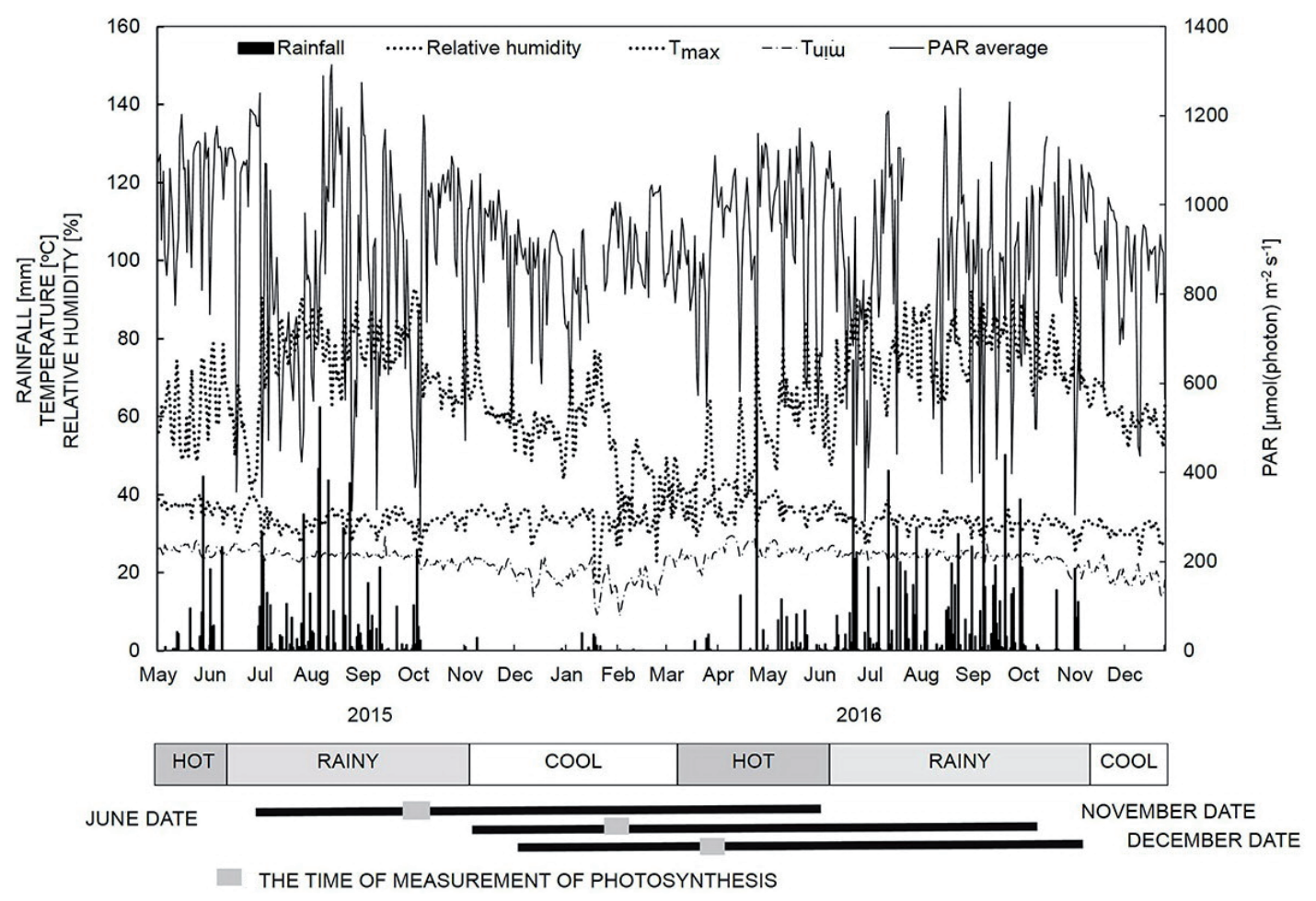

Fig. 1. Maximum temperature $\left(\mathrm{T}_{\max }\right)$, minimum temperature $\left(\mathrm{T}_{\min }\right)$, average photosynthetically active radiation (PAR average), relative humidity, and rainfall between May 2015-December 2016.

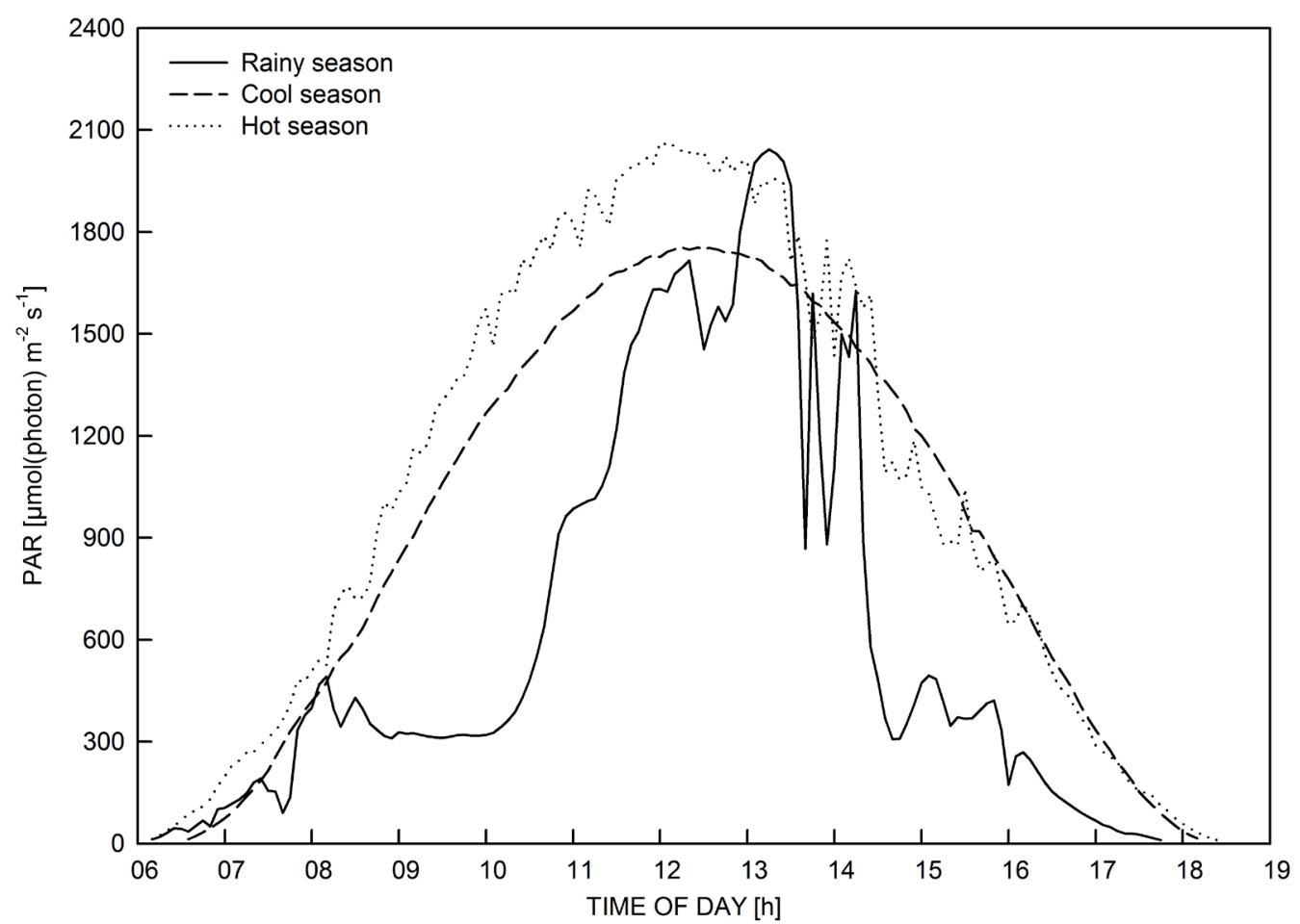

Fig. 2. Hourly PAR averaged from the two days of photosynthesis measurements in the three seasons.

the patterns of changes in PAR, air temperature, and RH were more or less similar to those in the irrigated fields. The maximum $P_{N}$ for the upper canopy leaves of plants growing under rainfed conditions was $17.8 \mu \mathrm{mol}\left(\mathrm{CO}_{2}\right)$ $\mathrm{m}^{-2} \mathrm{~s}^{-1}$ at 13:00 h under the PAR level of 1,132 $\mu \mathrm{mol}$ (photon) $\mathrm{m}^{-2} \mathrm{~s}^{-1}$ (Fig. 4B). The $P_{\mathrm{N}}$ of the middle and lower canopy leaves, on the other hand, reached the maximum as early as 9:00 $\mathrm{h}\left[10.5\right.$ and $8.3 \mu \mathrm{mol}\left(\mathrm{CO}_{2}\right) \mathrm{m}^{-2} \mathrm{~s}^{-1}$ under the PAR levels of 495 and $383 \mu \mathrm{mol}$ (photon) $\mathrm{m}^{-2} \mathrm{~s}^{-1}$, respectively]. The average diurnal $g_{\mathrm{s}}$ of cassava plants was $0.5 \mathrm{~mol}\left(\mathrm{H}_{2} \mathrm{O}\right)$ 


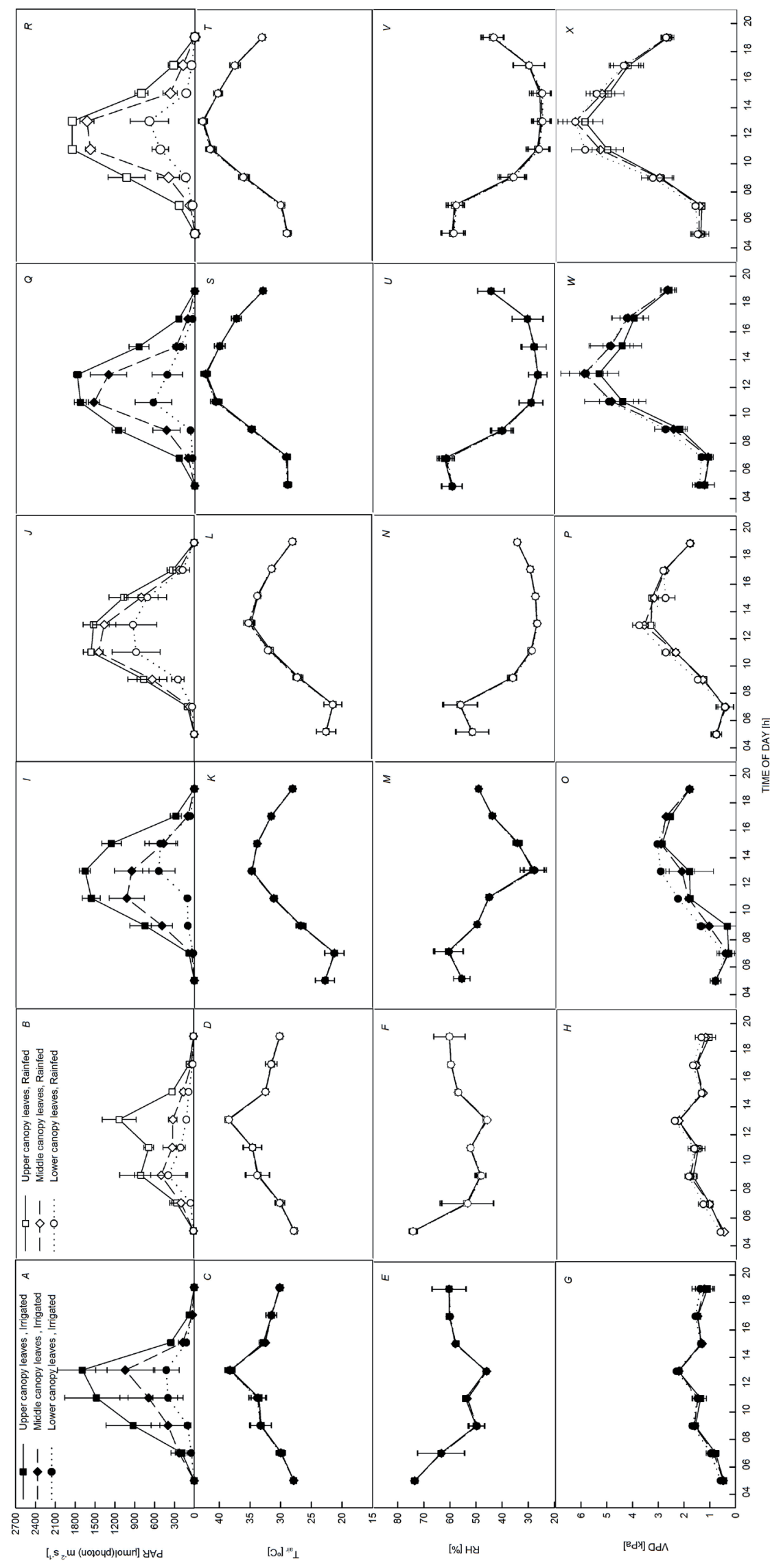

Fig. 3. Diurnal environmental parameters in the rainy $(A-H)$, cool $(I-P)$, and hot $(Q-X)$ season for the upper (dark line), middle (dashed line) and lower (dotted line) canopy leaves on the main stem of cassava 'RY9' under irrigated (closed symbol) and rainfed (open symbol) conditions. Mean $\pm \mathrm{SE}$ of four replicates. 


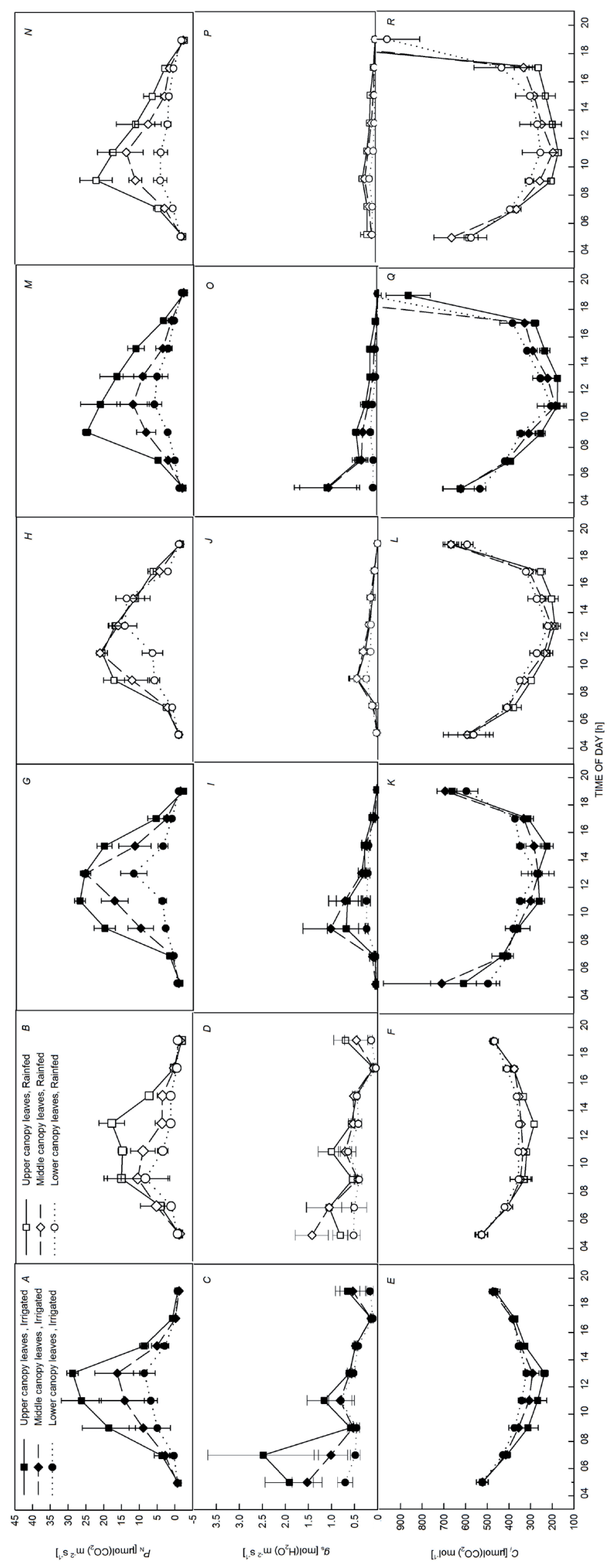

Fig. 4. Diurnal photosynthetic gas-exchange parameters in the rainy $(A-F)$, cool $(G-L)$, and hot $(M-R)$ season for the upper (dark line), middle (dashed line) and lower (dotted line) canopy leaves on the main stem of cassava 'RY9' under irrigated (closed symbol) and rainfed (open symbol) conditions. Mean $\pm \mathrm{SE}$ of four replicates. 


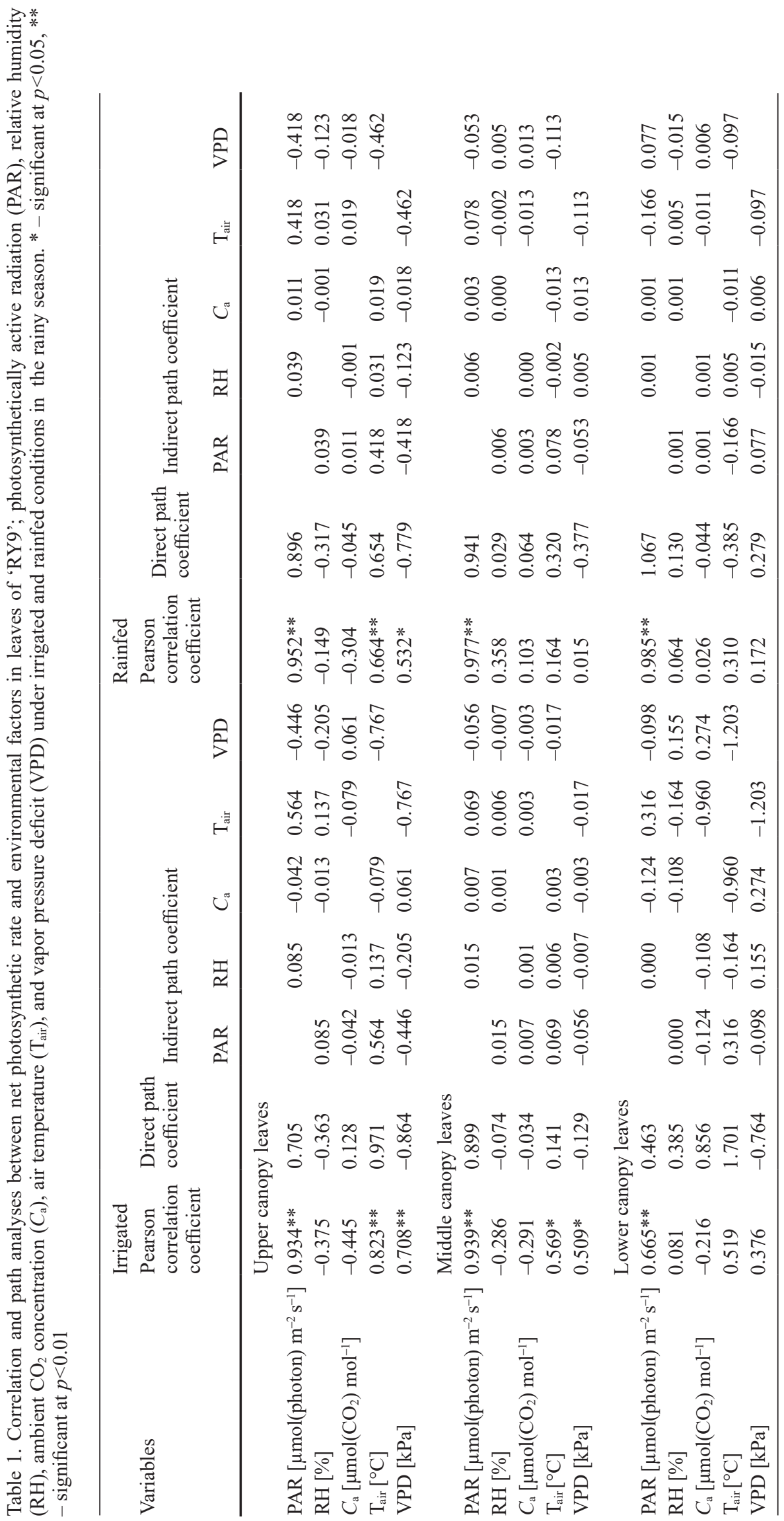




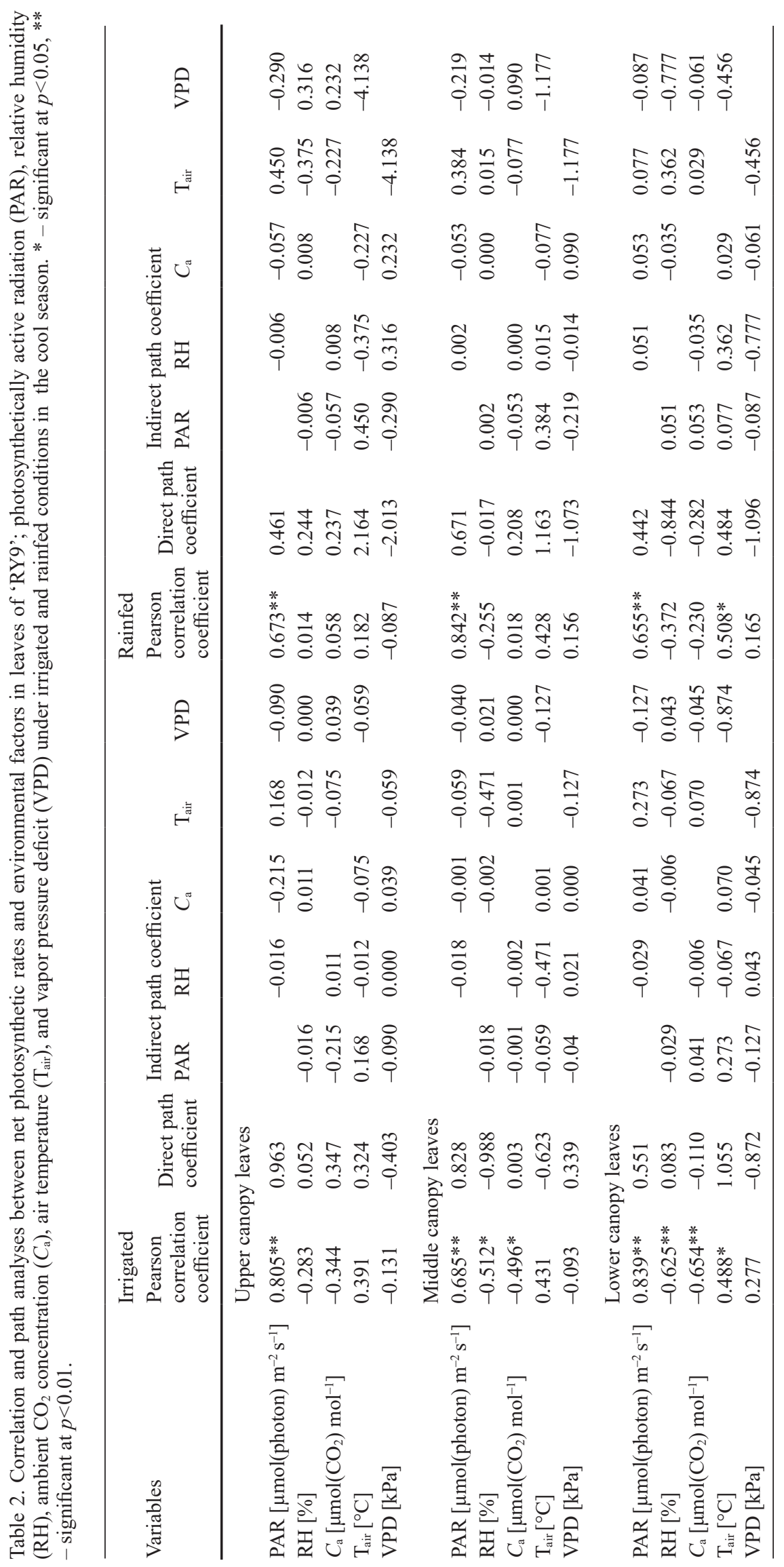


$\mathrm{m}^{-2} \mathrm{~s}^{-1}$ under both irrigated and rainfed conditions (Fig. 4C,D). The diurnal changes in $C_{\mathrm{i}}$ (Fig. 4E,F) were in the opposite direction to those of $P_{\mathrm{N}}$ with the lowest $C_{\mathrm{i}}$ recorded at 13:00 $\mathrm{h}$ [236.2 and $282.3 \mu \mathrm{mol}\left(\mathrm{CO}_{2}\right) \mathrm{mol}^{-1}$ for the upper canopy leaves of the irrigated and rainfed plants, respectively].

In the cool season, maximum $\mathrm{T}_{\text {air }}$, VPD, and minimum $\mathrm{RH}$ were reached at 13:00 $\mathrm{h}$ in both irrigated and rainfed plots (but the irrigated plot had maximum VPD at 15:00 h) (Fig. $3 K-P)$. However, maximum PAR was reached at 13:00 $\mathrm{h}$ in the irrigated field, while at 11:00 $\mathrm{h}$ in the rainfed plots (Fig. 4I,J). The patterns of changes in $P_{\mathrm{N}}$ were similar to those in the rainy season, except that the maximum $P_{\mathrm{N}}$ were reached at 11:00, 13:00 or 15:00 h depending on leaf positions. The maximum $P_{\mathrm{N}}$ of the upper canopy leaves of plants grown under irrigation was $26.9 \mu \operatorname{mol}\left(\mathrm{CO}_{2}\right) \mathrm{m}^{-2} \mathrm{~s}^{-1}$ at 11:00 $\mathrm{h}$ nder the PAR of $1,561 \mu \mathrm{mol}\left(\right.$ photon) $\mathrm{m}^{-2} \mathrm{~s}^{-1}$. The middle and lower canopy leaves performed maximum $P_{\mathrm{N}}$ at $13: 00 \mathrm{~h}[25.4$ and $11.8 \mu \mathrm{mol}\left(\mathrm{CO}_{2}\right) \mathrm{m}^{-2} \mathrm{~s}^{-1}$, respectively, Fig. $4 G$ ] with light intensity at 949 and $538 \mu \mathrm{mol}$ (photon) $\mathrm{m}^{-2} \mathrm{~s}^{-1}$, respectively (Fig. 3I). In the rainfed conditions, maximum $P_{\mathrm{N}}$ for the upper and middle canopy leaves [20.7 and $21.3 \mu \mathrm{mol}\left(\mathrm{CO}_{2}\right) \mathrm{m}^{-2} \mathrm{~s}^{-1}$, respectively, Fig. $\left.4 H\right]$ were recorded at 11:00 $\mathrm{h}$ at PAR of 1,563 and 1,448 $\mu$ mol(photon) $\mathrm{m}^{-2} \mathrm{~s}^{-1}$ (Fig. 3J), respectively. The lower canopy leaves showed the maximum $P_{\mathrm{N}}$ at 15:00 h $\left[13.7 \mu \mathrm{mol}\left(\mathrm{CO}_{2}\right) \mathrm{m}^{-2} \mathrm{~s}^{-1}\right.$, Fig. $\left.4 H\right]$ when they received the light intensity of $710.5 \mu \mathrm{mol}$ (photon) $\mathrm{m}^{-2} \mathrm{~s}^{-1}$ (Fig $3 J$ ). The maximum $g_{\mathrm{s}}$ occurred at 09:00 h [0.7 and $0.5 \operatorname{mol}\left(\mathrm{H}_{2} \mathrm{O}\right)$ $\mathrm{m}^{-2} \mathrm{~s}^{-1}$ for irrigated and rainfed plots, respectively] at upper canopy leaves, and decreased thereafter (Fig. 4I,J). The diurnal changes in $C_{\mathrm{i}}$ (Fig. $\left.4 K, L\right)$ were in the opposite direction to those of $P_{\mathrm{N}}$. Moreover, $C_{\mathrm{i}}$ values in the cool season tended to be lower than those in the rainy season with the lowest $C_{\mathrm{i}}$ of 224.2 and $186.1 \mu \mathrm{mol}\left(\mathrm{CO}_{2}\right) \mathrm{mol}^{-1}$ for the upper canopy leaves of the irrigated and rainfed plants, respectively.

In the hot season, higher temperature, VPD, and lower $\mathrm{RH}$ were more apparent in the hot than that in the rainy and cool seasons. Maximum temperature $\left(43.0^{\circ} \mathrm{C}\right.$ in the rainfed field) and minimum $\mathrm{RH}(25.4 \%$ in the rainfed field) were recorded at 13:00 h (Fig. $3 S-X)$. The upper canopy leaves showed maximum $P_{\mathrm{N}}$ of 25.1 and $22.2 \mu \mathrm{mol}\left(\mathrm{CO}_{2}\right) \mathrm{m}^{-2} \mathrm{~s}^{-1}$ for irrigated and rainfed conditions as early as 9:00 h, respectively (Fig. 4M,N), when they received the PAR of 1,150 and $1,032 \mu \mathrm{mol}$ (photon) $\mathrm{m}^{-2} \mathrm{~s}^{-1}$ (Fig. 3Q,R). Although the upper canopy leaves received higher PAR later on during the day [1,775 and 1,852 $\mu \mathrm{mol}\left(\right.$ photon $\mathrm{m}^{-2} \mathrm{~s}^{-1}$ at $13.00 \mathrm{~h}$ for the irrigated and rainfed plots, respectively], their photosynthesis decreased. The middle and lower canopy leaves of the irrigated plants showed maximum $P_{\mathrm{N}}$ at 11:00 h of 12.1 and $6.0 \mu \operatorname{mol}\left(\mathrm{CO}_{2}\right)$ $\mathrm{m}^{-2} \mathrm{~s}^{-1}$ (Fig. 4M), while they were exposed to PAR of 1,524 and $625 \mu \mathrm{mol}$ (photon) $\mathrm{m}^{-2} \mathrm{~s}^{-1}$ (Fig. $3 Q$ ). The middle canopy leaves of the rainfed plants achieved maximum $P_{\mathrm{N}}$ at 11:00 h, i.e., $13.8 \mu \mathrm{mol}\left(\mathrm{CO}_{2}\right) \mathrm{m}^{-2} \mathrm{~s}^{-1}$ (Fig. $4 N$ ) at PAR level of $1,579 \mu \mathrm{mol}$ (photon) $\mathrm{m}^{-2} \mathrm{~s}^{-1}$ (Fig. 3R), while the lower canopy leaves attained the maximum $P_{\mathrm{N}}$ at 9:00 and 11:00 h [4.20 and $4.10 \mu \mathrm{mol}\left(\mathrm{CO}_{2}\right) \mathrm{m}^{-2} \mathrm{~s}^{-1}$ at PAR of 440 and
$522 \mu \mathrm{mol}\left(\right.$ photon) $\mathrm{m}^{-2} \mathrm{~s}^{-1}$. The maximum $g_{\mathrm{s}}$ appeared at 09:00 $\mathrm{h}\left[0.5\right.$ and $0.3 \mathrm{~mol}\left(\mathrm{H}_{2} \mathrm{O}\right) \mathrm{m}^{-2} \mathrm{~s}^{-1}$ for the upper canopy leaves in the irrigated and rainfed plots, respectively], and decreased thereafter (Fig. 4I,J). The diurnal changes in $C_{\mathrm{i}}$ (Fig. $4 Q, R$ ) were in the opposite direction to those in $P_{\mathrm{N}}$, and $C_{\mathrm{i}}$ in the hot season tended to be lower than those in the rainy and cool seasons with the lowest $C_{\mathrm{i}}$ of 175.9 and $175.4 \mu \mathrm{mol}\left(\mathrm{CO}_{2}\right) \mathrm{mol}^{-1}$ for the upper canopy leaves of the irrigated and rainfed plants, respectively.

Correlation and path analysis of photosynthesis and environmental factors: In the rainy season, correlations between environmental factors and $P_{\mathrm{N}}$ of the upper canopy leaves of plants grown under both water regimes showed that PAR, $\mathrm{T}_{\text {air }}$, and VPD had highly significant effects on $P_{\mathrm{N}}$ (Table 1). However, for the middle canopy leaves, those environmental factors had significant effects only in the irrigated plants, i.e., PAR, $\mathrm{T}_{\text {air }}$, and $\mathrm{VPD}$, while the middle canopy leaves of the rainfed plants were influenced by PAR only. The $P_{\mathrm{N}}$ of the lower canopy leaves grown under both water regimes was highly significantly correlated with PAR only. Direct path coefficient analyses showed that PAR, $\mathrm{T}_{\text {air }}$, and VPD were the parameters with the same outcome as the results of the correlation in upper and middle canopy leaves. Path analysis showed that $\mathrm{T}_{\text {air }}$ VPD, and PAR were the three factors most strongly related to $P_{N}$ of the upper canopy leaves under both water regimes. For the middle canopy leaves under both water regimes, only PAR was the major factor influencing $P_{\mathrm{N}}$. Photosynthetic rates of the lower canopy leaves of the irrigated plants were influenced mostly by $\mathrm{T}_{\text {air }}$ followed by $C_{\mathrm{a}}$ and VPD, while PAR was the only determining factor for the rainfed plants.

In the cool season, only PAR had significant correlations with $P_{\mathrm{N}}$ of the upper canopy leaves of plants grown under both water regimes (Table 2). $P_{\mathrm{N}}$ of the middle canopy leaves of the irrigated plants were significantly correlated with PAR, RH, and $C_{\mathrm{a}}$, while that of the rainfed plants was correlated with PAR only. For the lower canopy leaves of irrigated plants, $P_{\mathrm{N}}$ were significantly correlated with PAR, RH, $C_{\mathrm{a}}$, and $\mathrm{T}_{\text {air }}$, while only PAR and $\mathrm{T}_{\text {air }}$ significantly influenced the rainfed plants. Direct path coefficient analyses for the irrigated plants showed that PAR was the most influential factor for photosynthesis of the upper canopy leaves, whereas PAR and RH were significant for the middle canopy leaves. On the other hand, $T_{\text {air }}$ and VPD imposed the strongest effects on the lower canopy leaves. For the rainfed plants, $T_{\text {air }}$ and VPD were the most important determining factors for the upper and middle canopy leaves, whereas RH and VPD had the strongest effects on the lower canopy leaves. When an indirect path coefficient analysis was carried out, very low coefficients were generally found for most factors.

In the hot season, PAR was the only parameter which had significant correlation with $P_{\mathrm{N}}$ of cassava leaves under irrigated (upper canopy leaves) and rainfed (leaves on all three positions). In addition, $\mathrm{T}_{\text {air }}$ was the only parameter significantly correlated with the lower canopy leaves of the irrigated plants (Table 3). Path coefficient analysis clearly showed that VPD was the primary determining 


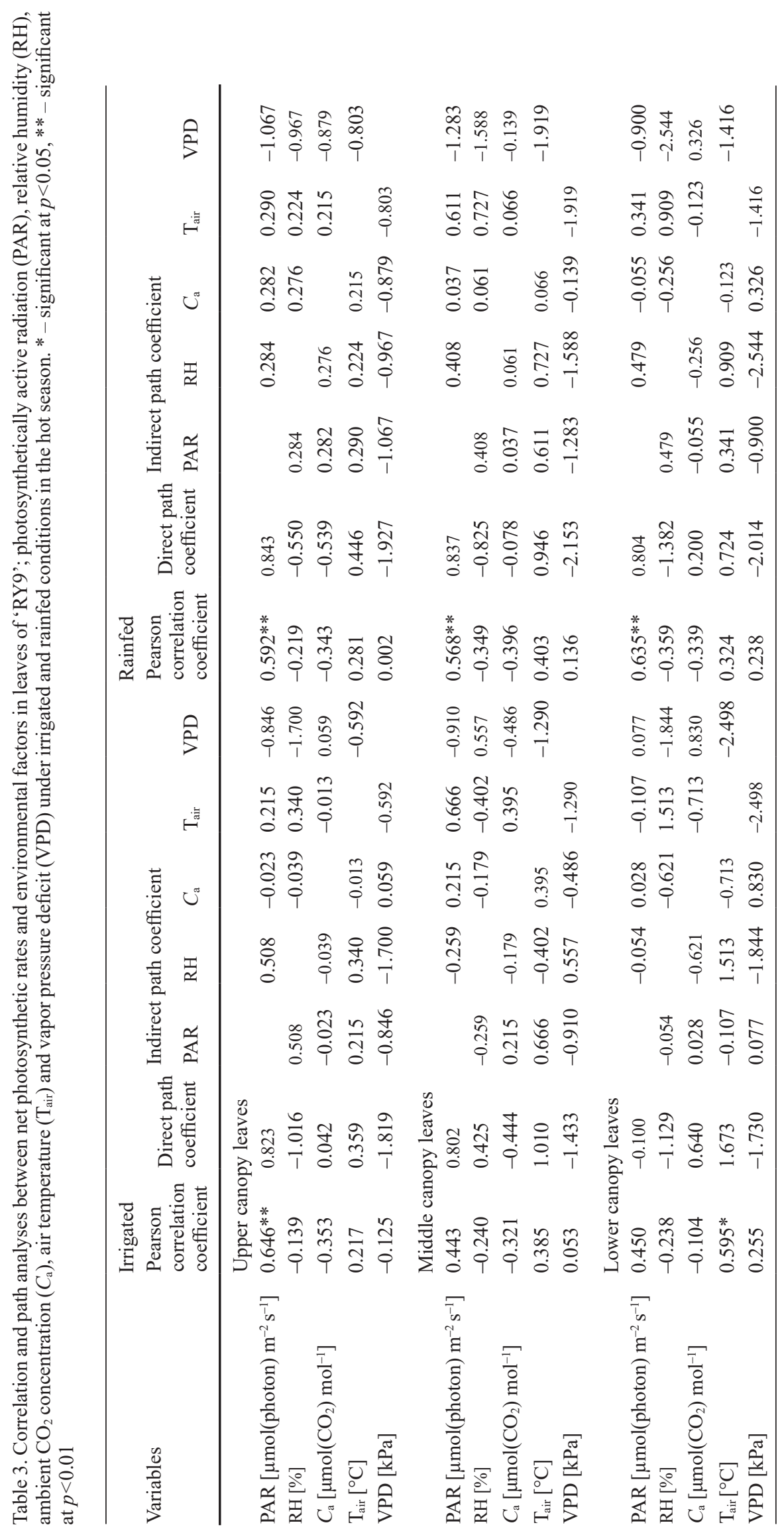




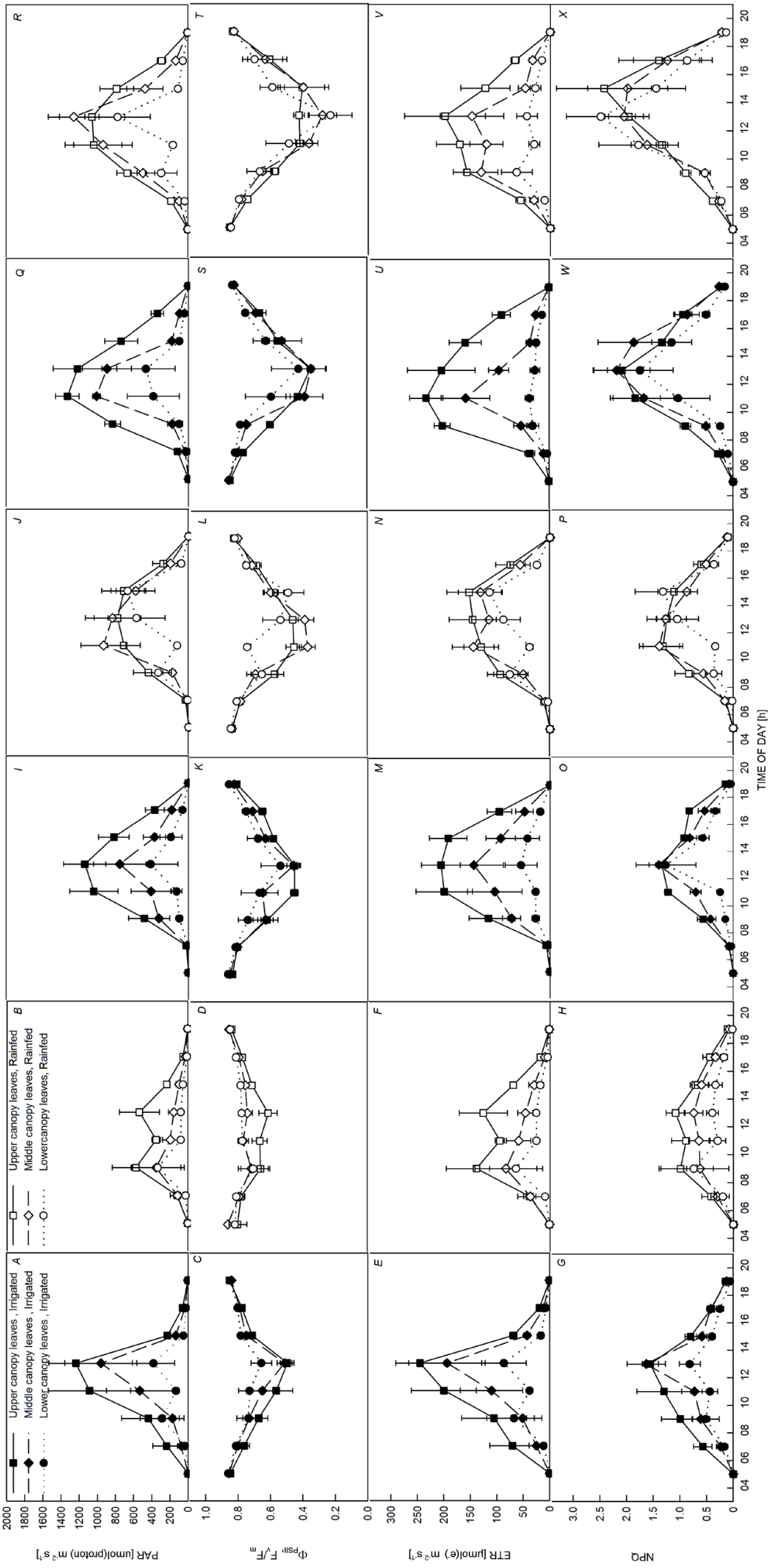

Fig. 5. Diurnal chlorophyll fluorescence of the upper (dark line), middle (dashed line), and lower (dotted line) canopy leaves on main stem of cassava 'RY9' at plant age of three months after planting under irrigated (closed symbol) and rainfed (open symbol) conditions in rainy $(A-H)$, cool $(I-P)$, and hot $(Q-X)$ seasons. Mean $\pm \mathrm{SE}$ of four replicates. 
factor with the highest coefficients determining $P_{\mathrm{N}}$ of cassava leaves in the hot season regardless of the water regimes and leaf positions. The second most important parameters for the irrigated plants were $\mathrm{RH}$ for the upper and $\mathrm{T}_{\text {air }}$ for the middle and lower canopy leaves. For the rainfed plants, PAR, $\mathrm{T}_{\text {air }}$, and $\mathrm{RH}$ were the second most important factors for the upper, middle and lower canopy leaves, respectively.

Diurnal changes in Chl fluorescence parameters: The $\mathrm{F}_{\mathrm{v}} / \mathrm{F}_{\mathrm{m}}$ measured in the dark at predawn $(05: 00 \mathrm{~h})$ was higher than 0.8. During the day, between 7:00-13:00 h, $\Phi_{\text {PSII }}$ decreased with increasing light intensity and then recovered in the late afternoon. The $\mathrm{F}_{\mathrm{v}} / \mathrm{F}_{\mathrm{m}}$ values measured in the dark at 19:00 $\mathrm{h}$ were generally as high as those measured at predawn. In contrast, ETR and NPQ was zero at predawn, increased with increasing light intensity, and then, in the late afternoon, decreased to reach zero at 19:00 h (Fig. 5).

In the rainy season, the $\mathrm{F}_{\mathrm{v}} / \mathrm{F}_{\mathrm{m}}$ values of the upper, middle, and lower canopy leaves under irrigated conditions were high and similar in the dark (at 5:00 h), i.e., 0.848, 0.856 , and 0.861 , respectively. Afterwards the $\Phi_{\text {PSII }}$ decreased with the increasing PAR. At 13:00 h, the $\Phi_{\text {PSII }}$ values of the upper, middle, and lower canopy leaves fell to the minimum of $0.497,0.513$, and 0.657 , respectively, and then were increasing during the late afternoon. The $\mathrm{F}_{\mathrm{v}} / \mathrm{F}_{\mathrm{m}}$ values measured in the dark at 19:00 $\mathrm{h}$ were 0.84, 0.82 , and 0.844 for the upper, middle, and lower canopy leaves, respectively (Fig. $5 C$ ). In the rainfed conditions, the $\mathrm{F}_{\mathrm{v}} / \mathrm{F}_{\mathrm{m}}$ values in the dark of the upper, middle, and lower canopy leaves were $0.809,0.868$, and 0.823 , respectively. The minimum $\Phi_{\text {PSII }}$ occurred at 13:00 $\mathrm{h}$ for the upper canopy leaves $(0.617)$ and at 9:00 $\mathrm{h}$ for the middle $(0.723)$ and lower (0.710) canopy leaves (Fig. 5D). The ETR and NPQ of the upper, middle, and lower canopy leaves were zero at predawn $(5: 00 \mathrm{~h})$ and increased during the day in response to light intensity. The maximum ETR, at 13:00 h, were $245.0,195.0$, and $86.4 \mu \mathrm{mol}\left(\mathrm{e}^{-}\right) \mathrm{m}^{-2} \mathrm{~s}^{-1}$ for the upper, middle, and lower canopy leaves of the irrigated plants, respectively (Fig. 5E), whereas the corresponding values for NPQ were $1.555,1.632$, and 0.814 (Fig. $5 G$ ). For the rainfed plants, maximum ETR occurred at 9:00 $\mathrm{h}$ and were $141.3,84.4$, and $64.5 \mu \mathrm{mol}\left(\mathrm{e}^{-}\right) \mathrm{m}^{-2} \mathrm{~s}^{-1}$ for the upper, middle, and lower canopy leaves, respectively (Fig. $5 F$ ). The maximum NPQ for the upper and middle canopy leaves recorded at 13:00 $\mathrm{h}$ were 1.074 and 0.738 , whereas that of the lower canopy leaves was 0.734 at 9:00 h (Fig. 5H).

In the cool season, the $\mathrm{F}_{\mathrm{v}} / \mathrm{F}_{\mathrm{m}}$ values of the upper, middle, and lower canopy leaves under irrigated conditions were $0.835,0.850$, and 0.861 , respectively, at predawn $(5: 00 \mathrm{~h})$. The lowest values of $\Phi_{\text {PSII }}$ recorded at $13: 00 \mathrm{~h}$ were 0.452 , 0.458 , and 0.538 for the upper, middle, and lower canopy leaves, respectively (Fig. $5 K$ ). In the rainfed conditions, the $\mathrm{F}_{\mathrm{v}} / \mathrm{F}_{\mathrm{m}}$ values in the dark of the upper, middle, and lower canopy leaves were $0.847,0.860$, and 0.866 , respectively. The minimum values of $\Phi_{\text {PSII }}$ for the rainfed plants were 0.459 and 0.374 for the upper and middle canopy leaves, respectively, at 11:00 $\mathrm{h}$, and 0.494 for the lower canopy leaves at 15:00 h (Fig. 5L). The maximum ETR at 13:00 h were $210.0,147.0$, and $55.4 \mu \mathrm{mol}\left(\mathrm{e}^{-}\right) \mathrm{m}^{-2} \mathrm{~s}^{-1}$ for the upper, middle, and lower canopy leaves of the irrigated plants, respectively (Fig. 5M), while the corresponding values for the rainfed plants were 156.3, 148.7, and $116.8 \mu \mathrm{mol}\left(\mathrm{e}^{-}\right) \mathrm{m}^{-2} \mathrm{~s}^{-1}$ (Fig. $5 N$ ). The maximum NPQ (at 13:00 h) for the upper, middle, and lower canopy leaves of the irrigated plants were 1.336, 1.394, and 1.254, respectively (Fig. 5O). For the rainfed plants, the maximum NPQ for the upper (1.318) and middle (1.380) canopy leaves were recorded at 11:00 $\mathrm{h}$ while that of the lower canopy leaves (1.318) occurred at 15:00 h (Fig. 5P).

In the hot season, the $\mathrm{F}_{\mathrm{v}} / \mathrm{F}_{\mathrm{m}}$ values at predawn of the upper, middle, and lower canopy leaves under irrigated conditions were $0.853,0.850$, and 0.861 , respectively, while those of the rainfed plants were $0.855,0.854$, and 0.848 (Fig. $5 S, T$ ). The lowest values of $\Phi_{\text {PSII }}$ were 0.352 , 0.348 , and 0.425 at $13: 00 \mathrm{~h}$ for the upper, middle, and lower canopy leaves of the irrigated plants, respectively (Fig. 5S). For the rainfed plants, the $\Phi_{\mathrm{PSII}}$ of the upper canopy leaves reached the minimum of 0.427 at 15:00, while the lowest values for the middle and lower canopy leaves were 0.284 and 0.233 at $13: 00 \mathrm{~h}$ (Fig. 5T). At night (19:00), the $\mathrm{F}_{\mathrm{v}} / \mathrm{F}_{\mathrm{m}}$ values for the irrigated plants were $0.833,0.827$, and 0.839 for the upper, middle, and lower canopy leaves, respectively. The corresponding $\mathrm{F}_{\mathrm{v}} / \mathrm{F}_{\mathrm{m}}$ values for the rainfed plants were $0.838,0.830$, and 0.829 . For the irrigated plants, the highest ETR were recorded at $11: 00 \mathrm{~h}$ and were $239.9,163.1$, and $38.5 \mu \mathrm{mol}\left(\mathrm{e}^{-}\right) \mathrm{m}^{-2} \mathrm{~s}^{-1}$ for upper, middle, and lower canopy leaves, respectively (Fig. 5U). The maximum ETR of the upper [202.9 $\mu \mathrm{mol}\left(\mathrm{e}^{-}\right)$ $\mathrm{m}^{-2} \mathrm{~s}^{-1}$ and middle [150.9 $\mu \mathrm{mol}\left(\mathrm{e}^{-}\right) \mathrm{m}^{-2} \mathrm{~s}^{-1}$ canopy leaves of the rainfed plants occurred at 13:00 h, while that of the lower canopy leaves $\left[64.7 \mu \mathrm{mol}\left(\mathrm{e}^{-}\right) \mathrm{m}^{-2} \mathrm{~s}^{-1}\right]$ was recorded earlier at 9:00 $\mathrm{h}$ (Fig. $5 \mathrm{~V}$ ). Under irrigation, the maximum NPQ for the upper, middle, and lower canopy leaves were $2.089,2.193$, and 1.747 , respectively, which were recorded at 13:00 h (Fig. $5 \mathrm{~W})$. For the rainfed plants, the maximum NPQ of the middle (2.018) and lower (2.449) leaves also occurred at 13:00 h but that of the upper canopy leaves (2.392) was shown at 15:00 h (Fig. 5X).

\section{Discussion}

Diurnal changes in $P_{\mathrm{N}}$ of cassava 'RY9' were closely related to changes in environmental conditions which varied in different seasons. In the rainy and cool seasons, diurnal pattern of $P_{\mathrm{N}}$ generally paralleled closely the pattern of changes in PAR during the day and exhibited a bell-shaped response curve reaching the maximum $P_{\mathrm{N}}$ between 11:00-13:00 h. However, diurnal response of $P_{\mathrm{N}}$ in the hot season showed a prominent peak very early at 9:00 $\mathrm{h}$ and continuously decreased thereafter. Patterns of diurnal $P_{\mathrm{N}}$ in cassava, similar to our observation in the rainy and cool season, were also reported (Rosenthal et al. 2012, Song et al. 2014). Moreover, Shirke and Pathre (2003) also reported that diurnal changes in $P_{\mathrm{N}}$ of Prosopis juliflora paralleled PAR most closely during spring when the environmental conditions were relatively mild. Generally, photosynthetic rates were higher in the morning than that 
in the afternoon and the effect was more pronounced in the cool/dry season than that in the wet season (Eamus and Cole 1997, Shirke and Pather 2003, Koyama and Takemoto 2014). Leaf temperature of Acacia and Eucalyptus tetrodonta is generally higher in the afternoon than in the morning (Eamus and Cole 1997, Prior et al. $1997 a$ ) as a result of both reduced $g_{\mathrm{s}}$ and transpirational cooling and warming of the ground beneath crop canopy (Fordyce et al. 1997, Prior et al. 1997a, 1997b). Higher leaf temperature $\left(42^{\circ} \mathrm{C}\right)$ in the afternoon, particularly in the hot climate, causes a reduction in photosynthesis due to lower $g_{\mathrm{s}}$ and $C_{\mathrm{i}}$ as well as enhanced oxidative stress in poplar (Populus simonii) (Song et al. 2014). In this study, leaf temperature also reached $42-43^{\circ} \mathrm{C}$ at around 13:00 $\mathrm{h}$ in the hot season (data not shown). Moreover, VPD is larger in the dry season than that in the wet season and larger in the afternoon than that in the morning (Duff et al. 1997), thus increased VPD in the afternoon and in the dry season reduces $g_{\mathrm{s}}$ and hence photosynthetic rate (Eamus and Cole 1997, Myers et al. 1997).

The conditions in the rainy season were the most favorable with high $\mathrm{RH}$, mild $\mathrm{T}_{\text {air, }}$ and high soil moisture with VPD lower than $2 \mathrm{kPa}$ throughout the day causing relatively high $g_{s}$. Therefore, the pattern of diurnal changes in $P_{\mathrm{N}}$ paralleled closely that of PAR achieving the maximum $P_{\mathrm{N}}$ at 13:00 h for both irrigated and rainfed plants. In a previous study, diurnal photosynthesis of cassava was measured in an Experimental Research Station in Urbana, Illinois during midsummer (JuneAugust) where the precipitation was $428 \mathrm{~mm}$, maximum daily temperature of $30^{\circ} \mathrm{C}$, and daily mean solar radiation of $26.35 \mathrm{MJ} \mathrm{m}^{-2}$ or $696.85 \mu \mathrm{mol}$ (photon) $\mathrm{m}^{-2} \mathrm{~s}^{-1}$ (more or less similar to rainy season in this study). The 3-monthold cassava plants had maximum $P_{\mathrm{N}}$ comparable to our study which also occurred around 13:00 h (Rosenthal et al. 2012). Correlation and path coefficient analysis (Table 1) revealed that the main factors, which influenced $P_{\mathrm{N}}$ in the rainy season, were PAR, $T_{\text {air, }}$ and VPD for upper canopy leaves which were fully exposed to outside environment (high temperature, high VPD). However, $P_{\mathrm{N}}$ of the middle canopy leaves was influenced by PAR only (Table 1) due to more favorable microenvironment (lower temperature and higher humidity inside canopy). Path coefficient analysis showed that the factors, which influenced $P_{\mathrm{N}}$ for irrigated crop, also determined $P_{\mathrm{N}}$ of rainfed plants, the most influential factor being the PAR (for all three leaf levels) and VPD (for upper canopy leaves). Variations in solar radiation are one of the main causes for seasonal variations in photosynthesis of several woody plant species (Hasler and Avissar 2007, Bonal et al. 2008, Renninger et al. 2010).

Environmental conditions during the cool season were less favorable than that during the rainy season due to low rainfall (Fig. 1), lower $T_{\text {air }}$, lower $\mathrm{RH}$, and higher VPD (Fig. 3), and low soil moisture (Fig. 1S - supplement). The patterns of changes in $P_{\mathrm{N}}$, however, were similar to those in the rainy season, except that the maximum $P_{\mathrm{N}}$ were reached at 11:00 or 13:00 h depending on the leaf position. $P_{\mathrm{N}}$ increases linearly with PAR reaching maximum at 11:00 h, but at 13:00 h, when RH plunged below 30\% and air temperature increased to $35^{\circ} \mathrm{C}, P_{\mathrm{N}}$ slightly decreased even though PAR still increased. Low RH in the cool season resulted in higher VPD, particularly in the rainfed field, which in turn induced a reduction in $g_{s}$. A decline in $g_{\mathrm{s}}$ on exposure to low RH or high VPD was observed in cassava with virtually no changes in leaf water potential, hence protecting the leaves from dehydration while remaining photosynthetically active (El-Sharkawy and Cock 1990, El-Sharkawy 2004, 2007). The main environmental factor determining $P_{\mathrm{N}}$ of the upper canopy leaves of irrigated plants was PAR whereas those for the rainfed plants included $\mathrm{T}_{\text {air }}$ and VPD due to the lower RH and hence, higher VPD in the rainfed field. Even though plants in the irrigated and rainfed plots received comparable levels of PAR, much lower $P_{\mathrm{N}}$ of the rainfed plants, particularly in the afternoon, was also due to lower soil moisture.

Climate in the hot season was the most stressful, exhibiting maximum $\mathrm{T}_{\text {air }}$ of $42.5^{\circ} \mathrm{C}$ for the irrigated and $43.0^{\circ} \mathrm{C}$ for the rainfed field at 13:00 $\mathrm{h}$, and lowest $\mathrm{RH}$ of around $25-27 \%$ during the afternoon hours. This resulted in the highest VPD of 5.7 and $6.1 \mathrm{kPa}$ in the irrigated and rainfed field, respectively. The rainfed field also had very low soil matric potential of $-90.7 \mathrm{kPa}$. The striking difference in photosynthesis in the hot compared to that in the rainy and cool seasons is that maximum $P_{\mathrm{N}}$ [25.1 and $22.2 \mu \mathrm{mol}\left(\mathrm{CO}_{2}\right) \mathrm{m}^{-2} \mathrm{~s}^{-1}$ for irrigated and rainfed plants, respectively] were reached as early as 9:00 h [at PAR of 1,150 and $1,032 \mu$ mol(photon) $\mathrm{m}^{-2} \mathrm{~s}^{-1}$ ] after which the $P_{\mathrm{N}}$ sharply decreased even though PAR was reaching the maximum at 13:00 $\mathrm{h}$ [1,775 and 1,852 $\mu$ mol(photon) $\mathrm{m}^{-2} \mathrm{~s}^{-1}$. Patterns of change in $P_{\mathrm{N}}$ followed closely that of $g_{\mathrm{s}}$ which attained the maximum $\left[0.5\right.$ and $0.3 \operatorname{mol}\left(\mathrm{H}_{2} \mathrm{O}\right)$ $\mathrm{m}^{-2} \mathrm{~s}^{-1}$ for irrigated and rainfed plots, respectively] at 9:00 h, thereafter the values decreased down to a minimum of $0.1 \mathrm{~mol}\left(\mathrm{H}_{2} \mathrm{O}\right) \mathrm{m}^{-2} \mathrm{~s}^{-1}$ suggesting continuous stomatal closure. While PAR was the most important primary determinant of diurnal $P_{\mathrm{N}}$ in the rainy and cool seasons, path analysis showed that VPD was clearly the most influential factor determining $P_{\mathrm{N}}$ in the hot season combining with the effects of $\mathrm{T}_{\text {air }}, \mathrm{RH}$, and PAR (Table 3). Moreover, the lower $P_{\mathrm{N}}$ of rainfed compared with the irrigated plants in the hot season was also influenced by low soil water potential.

The striking difference in diurnal response of $P_{\mathrm{N}}$ between the rainy season and hot season supported the notion that plants of Euphorbiaceae endure environmental stress, due to hot-dry air and water deficit stress, via a strict stomatal control as demonstrated in Jatropha curcas (Díaz-López et al. 2012, Sapeta et al. 2013), Ricinus communis (Sausen and Rosa 2010), and Manihot esculenta (El-Sharkawy et al. 1992, De Tafur et al. 1997, El-Sharkawy 2007, 2016). In the hot season, $g_{s}$ attained the maximum as early as 9:00 $\mathrm{h}$ when the VPD was close to $3.0 \mathrm{kPa}$, thereafter it decreased corresponding to increasing VPD which peaked at 13:00 $\mathrm{h}$ and remained higher than $3.0 \mathrm{kPa}$ throughout the afternoon. The strong stomatal response to changes in VPD in cassava is an important stress-avoidance mechanism for crops that have to endure a long dry period (El-Sharkawy 1990, El-Sharkarwy 2004, El-Sharkawy 2012, McAdam and Brodribb 2015, Merilo et al. 2018). 
The $F_{v} / F_{m}$ value in the dark measures the maximum efficiency of PSII when all PSII centers are open and is widely used as an indicator of photoinhibition caused by photodamage to PSII (Baker 2008, Gorbe and Calatayud 2012). The typical range for $F_{v} / F_{m}$ among vascular plants is $0.75-0.85$ for nonstressed plants and values below 0.75 indicate a stressful situation (Björkman and Demmig 1987, Bolhàr-Nordenkampf et al. 1989). In this study, there were no differences in $\mathrm{F}_{\mathrm{v}} / \mathrm{F}_{\mathrm{m}}$ measured in the dark before dawn $(5: 00 \mathrm{~h})$ and at night $(19: 00 \mathrm{~h})$ and both values were greater than 0.8 , irrespective of seasons and water regimes. This indicated that cassava plants growing in this climate had an efficient photoprotection mechanism and did not suffer from chronic photodamage even during the hot season under rainfed conditions. Cassava plants have developed diverse photoprotection mechanisms, such as minimizing light absorption by leaf drooping (El-Sharkawy 2007) and dissipation of excess excitation energy as heat through NPQ (Calatayud et al. 2000, De Souza et al. 2017). Efficiency of energy utilization by a leaf is reflected by $\Phi_{\text {PSII }}$ which is the proportion of the light energy absorbed by $\mathrm{Chl}$ associated with PSII that is used in photochemistry at different photon flux density, hence indicates the operating quantum efficiency of PSII electron transport (Maxwell and Johnson 2000, Murchie and Lawson 2013). Generally, $\Phi_{\text {PSII }}$ was high in the early morning $(7: 00 \mathrm{~h})$, then decreased in parallel with increasing PAR, and reached a minimum mostly at 13:00 $\mathrm{h}$. The highest minimum efficiency was recorded in the rainy followed by the cool and hot seasons. This decrease in $\Phi_{\text {PSII }}$ with increasing PAR occurred as a greater fraction of PSII reaction centers become "closed" (photoreduced) under higher light and were thus unable to use the absorbed light for photochemistry (Baker 2008, Maxwell and Johnson 2000). In the afternoon, $\Phi_{\text {PSII }}$ showed increasing trend with decreasing PAR and reached similar early morning (7:00 h) values at 17:00 h (around 0.7) only in the rainy season. Cassava leaves in the cool and hot season were less efficient in recovering the PSII photochemical efficiency and exhibited $\Phi_{\text {PSII }}$ values (at 17:00 h) around 0.6. This indicated that the interactions of irradiance and other environmental parameters such as temperature and VPD determined the efficiency of PSII photochemistry.

Typically, the diurnal curves of NPQ were parallel to the curves of PAR but changed in a reverse direction to that of $\Phi_{\text {PSII. }}$. When the efficiency of light utilization in photochemistry was low, NPQ processes were operating to dissipate excess absorbed energy as heat to protect PSII from photodamage caused by energized triplet excited state chlorophyll (Müller 2001). In this study, the NPQ curves showed marked differences between seasons. In the hot season, the maximum NPQ exhibited by cassava leaves in both irrigated and rainfed conditions were markedly greater than those in the rainy and cool seasons. The diurnal curves of ETR, in the rainy and cool seasons, were similar and parallel to the curves for PAR and $P_{\mathrm{N}}$, and generally showed concomitant peaks. Direct relationship between electron transport and $P_{\mathrm{N}}$ indicated that the majority of the reductants generated from electron transport were consumed by $\mathrm{CO}_{2}$ assimilation and other electron sinks were minimal (Edwards and Baker 1993). However, under more stressful conditions in the hot season, $P_{\mathrm{N}}$ peaked at 9:00 $\mathrm{h}$ after which ETR still increased to attain the maximum at 11:00 $\mathrm{h}$ for the irrigated and at 13:00 $\mathrm{h}$ for the rainfed conditions. This indicated that during the afternoon in the stressful hot season higher proportion of reductants generated from electron transport were allocated to alternative sinks. Similar increase in the ratio of electron transport to $\mathrm{CO}_{2}$ assimilation under stresses was also observed in Jatropha curcas under drought stress (Sapeta et al. 2013) and maize under cold stress (Fryer et al. 1998). The proposed alternative electron sinks under stressful conditions included nitrogen metabolism, $\mathrm{O}_{2}$ reduction via photorespiration, the Mehler reaction, transport of reductants to mitochondria via malate, and cyclic electron flow via PGR5/PGPR1 proteins (Alric and Johnson 2017). The diversion of reductants from $\mathrm{CO}_{2}$ assimilation to alternative electron sinks during stresses, which impose restriction to photosynthetic carbon assimilation, could be a mechanism for preventing photodamage to the photosynthetic apparatus that operates in conjunction with NPQ (Peltier et al. 2010).

The differences in diurnal photosynthesis parameters between the three leaf positions were determined by multiple environmental factors. Plant canopies are characterized by major reductions in light availability from canopy top to bottom (Hikosaka 2005, Kitajima et al. 2005). The $P_{\mathrm{N}}$ values decreased, while $C_{\mathrm{i}}$ increased, from upper to the lower canopy leaves indicating both shade and age effects. The higher $C_{\mathrm{i}}$ and lower $P_{\mathrm{N}}$ in lower canopy leaves were previously observed in 15 cassava cultivars (El-Sharkawy and de Tafur 2007) and has been attributed to nonstomatal limitations including decreased Rubisco amounts and activities related to age effects as also shown in other species, such as rice (Makino et al. 1983, Suzuki et al. 2009), grape vine (Bertamini and Nedunchezhian 2002), and pine (Warren and Adams 2001). The $P_{\mathrm{N}}$ of the sun-exposed upper canopy leaves was mainly influenced by PAR in all three seasons. In contrast, VPD and $\mathrm{T}_{\text {air }}$ rather than PAR became the determining factors in the cool, and VPD was the most prominent factor in the hot season. The extremely low $P_{\mathrm{N}}$ of the lower canopy leaves in the hot season was associated with the highest VPD caused by low $\mathrm{RH}$, high $\mathrm{T}_{\text {air }}$ as well as the influence from heat radiated from the hot soil. Soil temperature could be influential on plant growth, and photosynthesis of rice was reduced when soil temperature increased from $30-40^{\circ} \mathrm{C}$ (Sanoh et al. 2010). Whole canopy photosynthesis is determined not only by environmental factors but also photosynthesis capacity of leaves at different canopy levels. Photosynthesis at each canopy level is dependent upon canopy size and architecture which in turn determines microenvironment of the leaves, particularly light penetration. It has been suggested that yield of cassava can be improved by increasing PAR interception efficiency (primarily by optimizing LAI) and PAR conversion efficiency (mainly by increasing seasonal net photosynthetic rates) (El-Sharkawy 2004, Lahai 2013, De Souza et al. 2017). It can be concluded from this study that photosynthesis performance of cassava 'RY9', on sunny days, was comparable in the rainy and cool season, 
and slightly greater than that in the hot season. Growing under rainfed condition, it can tolerate high temperature, low air humidity and low soil water potential imposed during the whole afternoon in the hot season, and still maintained good health as indicated by high $\mathrm{F}_{\mathrm{v}} / \mathrm{F}_{\mathrm{m}}$ values at night. Moreover, the tight control of cassava stomata, via responses to changes in air humidity and soil water, and leaf movement in response to solar irradiance (heliotropism and paraheliotropism), as reported previously (El-Sharkawy et al. 2012) protect leaf photosynthetic apparatus from dehydration and photoinhibition.

\section{References}

Alric J., Johnson X.: Alternative electron transport pathways in photosynthesis: a confluence of regulation. - Curr. Opin. Plant Biol. 37: 78-86, 2017.

Alves A.A.C.: Cassava botany and physiology. - In: Hillocks R.J., Thresh J.M., Bellotti A.C. (ed.): Cassava: Biology, Production and Utilization. Pp. 67-90. CABI Publishing, New York 2002.

Baker N.R.: Chlorophyll fluorescence: a probe of photosynthesis in vivo. - Annu. Rev. Plant Biol. 59: 89-113, 2008.

Berg V.S., El-Sharkawy M.A., Hernandez A.D.P. et al.: Leaf orientation and water relations in cassava. - In: Annual Meeting of the American Society of Plant Physiologists. Pp. 186. Louisiana State University, Baton Rouge 1986.

Bertamini M., Nedunchezhian N.: Leaf age effects on chlorophyll, Rubisco, photosynthetic electron transport activities and thylakoid membrane protein in field grown grapevine leaves. - J. Plant Physiol. 159: 799-803, 2002.

Bertolli S.C., Souza G.M.: The level of environmental noise affects the physiological performance of Glycine max under water deficit. - Theor. Exp. Plant Physiol. 25: 36-45, 2013.

Björkman O., Demmig B.: Photon yield of $\mathrm{O}_{2}$ evolution and chlorophyll fluorescence characteristics at $77 \mathrm{~K}$ among vascular plants of diverse origins. - Planta 170: 489-504, 1987.

Bolhar-Nordenkampf H.R., Long S.P., Baker N.R. et al.: Chlorophyll fluorescence as a probe of the photosynthetic competence of leaves in the field: A review of current instrumentation. Func. Ecol. 3: 497-514, 1989.

Bonal D., Bosc A., Ponton S. et al.: Impact of severe dry season on net ecosystem exchange in the Neotropical rainforest of French Guiana. - Glob. Change Biol. 14: 1917-1933, 2008.

Calatayud P.A., Llovera E., Bois J.F. et al.: Photosynthesis in drought adapted cassava. - Photosynthetica 38: 97-104, 2000.

Chaves M.M., Oliveira M.M.: Mechanisms underlying plant resilience to water deficit: prospects for water-saving agriculture. - J. Exp. Bot. 55: 2365-2384, 2004.

Chazdon R.L. Pearcy R.W.: The importance of sunflecks for forest understory plants. - BioScience 41: 760-766, 1991.

Chetty C.C., Rossin C.B., Gruissem W. et al.: Empowering biotechnology in southern Africa: establishment of a robust transformation platform for the production of transgenic industry-preferred cassava. - New Biotechnol. 30: 136-143, 2013.

De Souza A.P., Massenburg L.N., Jaiswal D. et al.: Rooting for cassava: insights into photosynthesis and associated physiology as a route to improve yield potential. - New Phytol. 213: 50-65, 2017.

De Tafur S.M., El-Sharkawy M.A., Calle F.: Photosynthesis and yield performance of cassava in seasonally dry and semiarid environments. - Photosynthetica 33: 249-257, 1997.
Díaz-López L., Gimeno V., Simón I. et al.: Jatropha curcas seedlings show a water conservation strategy under drought conditions based on decreasing leaf growth and stomatal conductance. - Agr. Water Manage. 105: 48-56, 2012.

Ding L., Wang K.J., Jiang G.M. et al.: Diurnal variation of gas exchange, chlorophyll fluorescence, and xanthophyll cycle components of maize hybrids released in different years. Photosynthetica 44: 26-31, 2006.

Duff G.A., Myers B., Williams R.J. et al.: Seasonal patterns in soil moisture, VPD, tree canopy cover and predawn potential in a northern Australian savanna. - Aust. J. Bot. 45: 211-224, 1997.

Durako M.J.: Using PAM fluorometry for landscape-level assessment of Thalassia testudinum: can diurnal variation in photochemical efficiency be used as an ecoindicator of seagrass health? - Ecol. Ind. 18: 243-251, 2012.

Eamus D., Cole S.: Diurnal and seasonal comparisons of assimilation, phyllode conductance and water potential of three Acacia and one Eucalypt species in the wet-dry tropics of Australia. -Aust. J. Bot. 42: 33-40, 1997.

Edet M.A., Tijani-Eniola H., Lagoke S.T.O. et al.: Relationship of cassava growth parameters with yield, yield related components and harvest time in Ibadan, Southwestern Nigeria. - J. Nat. Sci. Res. 5: 87-92, 2015.

Edwards G.E., Baker N.R.: Can $\mathrm{CO}_{2}$ assimilation in maize leaves be predicted accurately from chlorophyll fluorescence analysis? - Photosynth. Res. 37: 89-102, 1993.

El-Sharkawy M.A., Cock J.H.: Photosynthesis of cassava (Manihot esculenta). - Exp. Agric. 26: 325-340, 1990.

El-Sharkawy M.A., Cock J.H.: Water use efficiency of cassava. I. Effects of air humidity and water stress on stomatal conductance and gas exchange. - Crop Sci. 24: 497-502, 1984.

El-Sharkawy M.A., De Tafur S.M., Cadavid L.F.: Potential photosynthesis of cassava as affected by growth conditions. Crop Sci. 32: 1336-1342, 1992.

El-Sharkawy M.A., De Tafur S.M., Lopez Y.: Eco-physiological research for breeding improved cassava cultivars in favorable and stressful environments in tropical/subtropical biosystems. - Environ. Res. J. 6: 143-211, 2012.

El-Sharkawy M.A., De Tafur S.M.: Genotypic and within canopy variation in leaf carbon isotope discrimination and its relation to short term leaf gas exchange characteristics in cassava grown under rainfed conditions in the tropics. Photosynthetica 45: 515-526, 2007.

El-Sharkawy M.A.: Cassava biology and physiology. - Plant Mol. Biol. 56: 481-501, 2004.

El-Sharkawy M.A.: Effects of humidity and wind on leaf conductance of field grown cassava. - Rev. Bras. Fisiol. Veget. 2: 17-22, 1990.

El-Sharkawy M.A.: International research on cassava photosynthesis, productivity, ecophysiology, and responses to environmental stresses in the tropics. - Photosynthetica 44: 481-512, 2006.

El-Sharkawy M.A.: Physiological characteristics of cassava tolerance to prolonged drought in the tropics: Implications for breeding cultivars adapted to seasonally dry and semiarid environments. - Braz. J. Plant Physiol. 19: 257-286, 2007.

El-Sharkawy M.A.: Prospects of photosynthetic research for increasing agricultural productivity, with emphasis on the tropical $\mathrm{C}_{4}$ Amaranthus and the cassava $\mathrm{C}_{3}-\mathrm{C}_{4}$ crops. Photosynthetica 54: 161-184, 2016.

El-Sharkawy M.A.: Stress tolerant cassava: The role of integrative eco-physiology breeding research in crop improvement. Open J. Soil Sci. 2:162-186, 2012.

FAO: Food Outlook Biannual Report on Global Food Markets: Cassava. Pp. 34-39. Food and Agriculture Organization of the 
United Nations, Rome 2017.

Flexas J., Barón M., Bota J. et al.: Photosynthesis limitations during water stress acclimation and recovery in the droughtadapted Vitis hybrid Richer-110 (V. berlandieri $\mathrm{x}$ V. rupestris). - J. Exp. Bot. 60: 2361-2377, 2009.

Fordyce I.R., Duff G.A., Eamus D.: The water relations of Allosyncarpia ternata at contrasting sites in the monsoonal tropics of northern Australia. - Aust. J. Bot. 45: 259-274, 1997.

Freed R.D., Nissen O.: MSTAT-C Version 1.42. Michigan State University, East Lansing, Michigan 1992.

Fryer M.J., Andrews J.R., Oxborough K. et al.: Relationship between $\mathrm{CO}_{2}$ assimilation, photosynthetic electron transport, and active $\mathrm{O}_{2}$ metabolism in leaves of maize in the field during periods of low temperature. - Plant Physiol. 116: 571580, 1998 .

Genty B., Briantais J.M., Baker N.R.: The relationship between the quantum yield of photosynthetic electron transport and quenching of chlorophyll fluorescence. - Biochim. Biophys. Acta. 990: 87-92, 1989.

Geiger D.R., Servaites J.C.: Diurnal regulation of photosynthetic carbon metabolism in $\mathrm{C}_{3}$ plants. - Annu. Rev. Plant Phys. 45: 235-256, 1994.

Gomez K.A., Gomez A.A.: Statistical Procedures for Agricultural Research. Pp. 1-628. John Wiley \& Sons, New York 1984.

Gorbe E., Calatayud A.: Applications of chlorophyll fluorescence imaging technique in horticultural research: a review. - Sci. Hortic.-Amsterdam 138: 24-35, 2012.

Hasler N., Avissar R.: What controls evapotranspiration in the Amazon basin? - J. Hydrometeorol. 8: 380-395, 2007.

Hazrati S., Tahmasebi-Sarvestani Z., Modarres-Sanavy S.A.M. et al:: Effects of water stress and light intensity on chlorophyll fluorescence parameters and pigments of Aloe vera L. - Plant Physiol. Bioch. 106: 141-148, 2016.

Hikosaka K.: Leaf canopy as a dynamic system: ecophysiology and optimality in leaf turnover. - Ann. Bot.-London 95: 521533,2005 .

Hirasawa T., Hsiao T.C.: Some characteristics of reduced leaf photosynthesis at midday in maize growing in the field. Field Crop. Res. 62: 53-62, 1999.

Huang L.F., Zheng J.H., Zhang Y.Y. et al.: Diurnal variations in gas exchange, chlorophyll fluorescence quenching and light allocation in soybean leaves: The cause for midday depression in $\mathrm{CO}_{2}$ assimilation. - Sci Hortic.-Amsterdam 110: 214-218, 2006.

Huner N.P.A, Öquist G., Sarhan F.: Energy balance and acclimation to light and cold. - Trends Plant Sci. 3: 224-230, 1998.

IPCC: The climate system: an overview. - In: Houghton J.T., Ding Y., Griggs D.J. et al. (ed.): Climate Change 2001: The Scientific Basis. Contribution of Working Group I in the Third Assessment Report of Intergovernmental Panel on Climate Change. Pp. 85-98. Cambridge University Press, Cambridge 2001.

Kalaji H.M., Schansker G., Ladle R.J. et al.: Frequently asked questions about in vivo chlorophyll fluorescence: practical issues. - Photosynth. Res. 122: 121-158, 2014.

Keeratikasikorn P.: Soil of Northeast Thailand. Pp. 81-95. Faculty of Agriculture, Khon Kaen University. Khon Kaen 1991.

Kitajima K., Mulkey S.S., Wright J.: Variation in crown light utilization characteristics among tropical canopy trees. - Ann. Bot. 95: 535-547, 2005.

Koyama K., Takemoto S.: Morning reduction of photosynthetic capacity before midday depression. - Sci. Rep. 4: 4389, 2014.

Lahai T., Ekamayake I.J., Koroma J.P.C.: Influence of canopy structure on yield of cassava cultivars at various consequences of an inland valley agro-ecosystem. - J. Agric. Biotech. Sustain. Dev. 5: 36-47, 2013.

Lancaster P.A., Brooks J.E.: Cassava leaves as human food. Econ. Bot. 37: 331-348, 1983.

Latif S., Müller J.: Potential of cassava leaves in human nutrition: a review. - Trends Food Sci. Technol. 44: 147-158, 2015.

Li H., Zhang G.C., Xie H.C. et al.: The effects of the phenol concentrations on photosynthetic parameters of Salix babylonica L. - Photosynthetica 53: 430-435, 2015.

Li X.W., Chen S.L.: Diurnal changes in gas exchange and chlorophyll fluorescence parameters of Fritillaria cirrhosa and F. Delavayi under field conditions. - Photosynthetica 47: 191-198, 2009.

Logan B.A., Adams III W.W., Demmig-Adams B.: Avoiding common pitfalls of chlorophyll fluorescence analysis under field conditions. - Funct. Plant Biol. 34: 853-859, 2007.

Lukuyu B., Okike I., Duncan A. et al.: Use of Cassava in Livestock and Aquaculture Feeding Programs. ILRI Discussion Paper 25. Pp. 83. International Livestock Research Institute, Nairobi 2014.

Makino A., Mae T., Ohira K.: Photosynthesis and ribulose 1,5- bisphosphate carboxylase in rice leaves. Changes in photosynthesis and enzymes involved in carbon assimilation from leaf development through senescence. - Plant Physiol. 73: 1002-1007, 1983.

Maxwell K., Johnson G.N.: Chlorophyll fluorescence - a practical guide. - J. Exp. Bot. 51: 659-668, 2000.

McAdam S.A.M., Brodribb T.J.: The evolution of mechanisms driving the stomatal response to vapor pressure deficit. - Plant Physiol. 167: 833-843, 2015.

Merilo E., Yarmolinsky D., Jalakas P. et al.: Stomatal VPD Response: There is more to the story than ABA. - Plant Physiol. 176: 851-864, 2018.

Müller P., Li X.-P., Niyogi K.K.: Non-photochemical quenching: a response to excess light energy. - Plant Physiol. 125: 15581566, 2001.

Murchie E.H., Lawson T.: Chlorophyll fluorescence analysis: a guide to good practice and understanding some new applications. - J. Exp. Bot. 64: 3983-3998, 2013.

Murchie E.H., Pinto M., Horton P.: Agriculture and the new challenges for photosynthesis research. - New Phytol. 181: 532-552, 2008.

Myers B., Duff G.A., Eamus D. et al.: Seasonal variations in water relations of trees of differing phenology in a wet-dry tropical savanna near Darwin, NT. - Aust. J. Bot. 45: 225240, 1997.

Nassar N., Ortiz R.: Breeding cassava. - Sci. Am. 302: 78-84, 2010.

Office of Agricultural Economics: Cassava: planted area, harvested area and yield in 2016. Dryad digital repository. http://www.oae.go.th/assets/portals/1/files/production/ cassava_dit.pdf, 2018.

Okogbenin E., Setter T.L., Ferguson M. et al.: Phenotypic approaches to drought in cassava: review. - Front. Physiol. 4: 1-15, 2013.

Okogbenin E., Setter T.L., Ferguson M. et al:: Phenotyping cassava for adaptation to drought. - In: Monneveux P., Ribaut J.-M. (ed.): Drought Phenotyping in Crops: from Theory to Practice. Pp. 381-400. CIMMYT/Generation Challenge Programme, Mexico City 2010.

Oliveira E. C., Miglioranza E.: Stomatal density in six genotypes of cassava. - Int. J. Eng. Sci. Inov. Technol. 3: 305-308, 2014.

Parry M.A.J., Reynolds M., Salvucci M.E. et al.: Raising yield potential of wheat. II. Increasing photosynthetic capacity and efficiency. - J. Exp. Bot. 62: 453-467, 2011.

Pearcy R.W.: Sunflecks and photosynthesis in plant canopies. - 
Annu. Rev. Plant Phys. 41: 421-453, 1990.

Pearcy R.W., Way D.A.: Two decades of sunfleck research: looking back to move forward. - Tree Physiol. 32: 1059-1061, 2012.

Peltier G., Tolleter D., Billon E. et al.: Auxiliary electron transport pathways in chloroplasts of microalgae. - Photosynth. Res. 106: 19-31, 2010.

Prior L., Eamus D., Duff G.A.: Seasonal and diurnal patterns of carbon assimilation, stomatal conductance, leaf water potential of Eucalyptus tetrodontasaplings in a wet-dry savanna in Northern Australia. - Aust. J. Bot. 45:241-258, 1997a.

Prior L., Eamus D., Duff G.A.: Seasonal trends in carbon assimilation, stomatal conductance, predawn leaf water potential and growth of Terminalia ferdinandiana, a deciduous tree of northern Australia. - Aust. J. Bot. 45: 53-69, $1997 \mathrm{~b}$.

Ravindra V.: Cassava leaves as animal feed: potential and limitations. - J. Sci. Food Agric. 61: 141-150, 1993.

Renninger H. J., Phillips N., Salvucci G.D.: Wet vs. dry season transpiration in an Amazonian rain forest palm Iriartea deltoidea. - Biotropica 42: 470-478, 2010.

Rosenqvist E., van Kooten O.: Chlorophyll fluorescence: a general description and nomenclature. - In: DeEll, J.R., Toivonen P.M.A. (ed.): Practical Applications of Chlorophyll Fluorescence in Plant Biology. Pp. 31-77. Kluwer Academic Publ, Dordrecht - Boston - London 2003.

Rosenthal D.M., Slattery R.A., Miller R.E. et al.: Cassava aboutFACE: greater than expected yield stimulation of cassava (Manihot esculenta) by future $\mathrm{CO}_{2}$ levels. - Glob. Change Biol. 18: 2661-2675, 2012.

Saibo N.J.M., Lourenço T., Oliveira M.M.: Transcription factors and regulation of photosynthetic and related metabolism under environmental stresses. - Ann. Bot.-London 103: 609623, 2009.

Sanoh Y., Ishimaru T., Ohsumi A. et al.: Effects of soil temperature on growth and root function in rice. - Plant Prod. Sci. 13: 235242, 2010.

Sapeta H., Costa J.M, Lourenço T. et al.: Drought stress response in Jatropha curcas: growth and physiology. - Environ. Exp. Bot. 85: 76-84, 2013.

Sausen T.L., Rosa L.M.G.: Growth and carbon assimilation limitations in Ricinus communis (Euphorbiaceae) under soil water stress conditions. - Acta Bot. Bras. 24: 648-654, 2010.

Shirke P.A., Pathre U.V.: Diurnal and seasonal changes in photosynthesis and photosystem 2 photochemical efficiency in Prosopis juliflora leaves subjected to natural environmental stress. - Photosynthetica 41: 83-89, 2003.

Song Y., Chen Q., Ci D. et al.: Effects of high temperature on photosynthesis and related gene expression in poplar. - BMC Plant Biol. 14: 111, 2014.

Suzuki Y., Miyamoto T., Yoshizawa R. et al.: Rubisco content and photosynthesis of leaves at different positions in transgenic rice with an over expression of RBCS. - Plant Cell Environ. 32: 417-427, 2009.

Thai Meteorological Department: Season of Thailand. Dryad Digital Repository. https://www.tmd.go.th/info/ info. php?FileID=53, 2016.

Turyagyenda L., Kizito E.B., Ferguson M. et al.: Physiological and molecular characterization of drought responses and identification of candidate tolerance genes in cassava. - AoB Plants 5: plt007, 2013.

Vitolo H.F., De Souza G.M., Silveira J.A.G.: Cross-scale multivariate analysis of physiological responses to high temperature in two tropical crops with $\mathrm{C}_{3}$ and $\mathrm{C}_{4}$ metabolism. - Environ. Exp. Bot. 80: 54-62, 2012.

Warren C.R., Adams M.A.: Distribution of N, Rubisco and photosynthesis in Pinus pinaster and acclimation to light. Plant Cell Environ. 24: 597-609, 2001.

Watson M.E., Brown J.R.: pH and lime requirement. - In: Brown J.R. (ed.): Recommended Chemical Soil Test Procedures for the North Central Region. North Central Regional Publ. 221 (revised). Publ. SB 1001. Pp. 13-16. Missouri Exp. Station, Columbia 1998.

Wuenscher J.E., Kozlowski T.T.: Relationship of gas exchange resistance to tree-seedling ecology. - Ecology 52: 1016-1023, 1971.

Yan W.M., Zhong Y., Shangguan Z.: A meta-analysis of leaf gas exchange and water status responses to drought. - Sci. Rep. 6 : 20917: doi:10.1038/srep20917, 2016.

Zha T.S., Wu Y.J., Jia X. et al.: Diurnal response of effective quantum yield of PSII photochemistry to irradiance as an indicator of photosynthetic acclimation to stressed environments revealed in a xerophytic species. - Ecol. Indic. 74: 191-197, 2017.

(C) The authors. This is an open access article distributed under the terms of the Creative Commons BY-NC-ND Licence. 